\title{
Environmental changes and plant use during the 5th-14th centuries in medieval Gdańsk, northern Poland
}

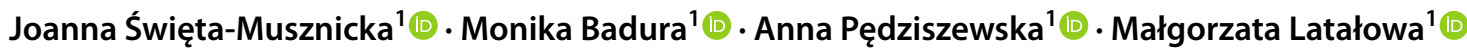

Received: 31 January 2020 / Accepted: 24 April 2020 / Published online: 30 July 2020

(c) The Author(s) 2020

\begin{abstract}
This paper reviews the results of the many years of investigations on the ecological aspects of settlement development in the oldest districts of the city of Gdańsk, the impacts of the changing climate and growing human pressure on the local environment, as well as the question of plant use by the inhabitants during the Middle Ages. Before the settlement was established, the landscape was dominated by alder woods and shallow water bodies of the extensive wetlands in the Wisła estuary. An important factor making settlement possible was probably the lowering of the water table around the 9th-10th centuries AD, causing a reduction of wetland. Archaeobotanical results are consistent with archaeological data on the periods at which particular town districts were settled. They provide evidence of the earliest changes to the natural environment, starting in the Stare Miasto ("Old Town") in the 11th-12th centuries, in the Główne Miasto ("Main Town") in the 12th-13th centuries, and on Wyspa Spichrzów ("Granary Island") during the 13th-14th centuries. The gradual expansion of the town caused a diversification of the local flora. Natural wetland communities and semi-natural wet meadows and pastures were still common within the settled area until the 14th century. On the other hand, the rapid spread of built-up areas, roads and gardens allowed the growth of ruderal vegetation there. Archaeobotanical and historical evidence shows the diverse and changing plant foods in the diet of the inhabitants during the Middle Ages.
\end{abstract}

Keywords Anthropogenic vegetation · Archaeobotany $\cdot$ Medieval Climate Anomaly $\cdot$ Medieval town development $\cdot$ Urban ecology $\cdot$ Useful plants $\cdot$ Wetland change

\section{Introduction}

The ecological aspects of the establishment and development of ancient towns are still poorly considered. For many years, the issues of material culture as well as the social and cultural changes were explored mainly by archaeologists and historians, while natural sciences, if involved, concentrated mainly on the economic aspects of plant and animal uses. However, especially in recent decades, there has been

Communicated by K.-E. Behre.

Electronic supplementary material The online version of this article (https://doi.org/10.1007/s00334-020-00789-9) contains supplementary material, which is available to authorized users.

Joanna Święta-Musznicka

j.musznicka@ug.edu.pl

1 Laboratory of Palaeoecology and Archaeobotany, Department of Plant Ecology, Faculty of Biology, University of Gdańsk, ul. Wita Stwosza 59, 80-308 Gdańsk, Poland a growing involvement of the natural sciences in studies of past urban societies. They offer us a better understanding of the environmental changes which took place both in the towns themselves and within their closest surroundings. The role of archaeobotany is of prime importance in this respect. It provides information on how plants were used by people (Wasylikowa 1978; Behre 1983; Märkle 2005; Mariotti Lippi et al. 2013) and on the effects of human activity upon the flora and vegetation during the stages of settlement development (Brun 2009; Pokorná 2017). Complex palaeoenvironmental studies based on different methods are also undertaken more and more often to reconstruct the ecological context of the progressing town development (Hall and Kenward 2004; Kisielienè et al. 2012; Kozáková et al. 2014; Stivrins et al. 2015). Combined results from pollen and macroscopic plant and animal remains in the natural sediments, cultural layers and other archaeological contexts make it possible to reconstruct past local ecosystems in particular periods at the urban centres (Latałowa 1999; Bosi et al. 2011; Pokorná et al. 2014). Pollen analysis also forms 
the basis for the reconstruction of the history of regional landscape changes (Greig 1992; Bosi et al. 2015; Mercuri et al. 2015). The broadening of the range of analyses with non-pollen palynomorphs (NPPs) (van Geel 2001), geochemical analyses (Holliday and Gartner 2007; Oonk et al. 2009) and micromorphology of sediments (Macphail et al. 1990) adds to our knowledge of the conditions of the formation of cultural layers (Alexandrovskaya and Alexandrovskiy 2000; Matthews 2010; Mazurek et al. 2016), the living conditions (Florenzano et al. 2012; Brinkkemper and van Haaster 2012; Pichler et al. 2014), heavy metal pollution (Hudson-Edwards and Maclin 1999; Cook et al. 2005; Kowalska et al. 2016) and specific uses of urban space (Cook et al. 2014; Banerjea et al. 2017; Wouters et al. 2017; Borderie et al. 2020) as well as the transformation of rural areas into urban centres (Petersén et al. 2015). Unfortunately, since undisturbed sediment sequences are difficult to obtain from urban sites, high temporal resolution multiproxy studies are still relatively rare (Latałowa 1999; Beneš et al. 2002; Stančikaitè et al. 2008; Bosi et al. 2015).

In Gdańsk, archaeobotanical research dates back to the 1950s. Most of those earliest publications are short reports containing a list of plant taxa, usually without a detailed interpretation of the data. Nevertheless, they provide important information, especially on plant use (Mądalski 1952; Moldenhawer 1952, 1953; Lechnicki 1955; Klichowska 1959; Lechnicki et al. 1961). A new stage in archaeobotanical investigations in Gdańsk began in 1998, when regular research started by our team in the Laboratory of Palaeoecology and Archaeobotany at the University of Gdańsk. Cooperation with the archaeological teams from the Archaeological Museum of Gdańsk, the Historical Museum of Gdańsk, the Institute of Archaeology at the University of Warsaw (a research team in Gdańsk) and the National Heritage Board of Poland helped to obtain materials from the earliest settlement areas in the city. The vast amount of research which has been done with a coherent approach and methodology (Latałowa et al. 2007) has made it possible to gather wellstructured information from many different features in several parts of the town and representing various historical periods. The abundance of the finds, the broad representation of useful plants as well as those typical of both natural communities and ones created by human activities have made it possible to study not only plant uses but also many ecological aspects of changing environment. The latter are significant in terms of the development of the town and the living conditions of its inhabitants (Latałowa et al. 2009b).

There are several papers on the use of crops as well as plants gathered from the wild in particular periods of the history of Gdańsk (Latałowa et al. 2001, 2003; Badura et al. 2005; Badura 2011; Pińska et al. 2013; Badura and Latałowa 2016, 2018). Special attention has been given to the use of plants for medical purposes (Badura and Pińska 2010) and the role of plant products in trade, including the import of luxury commodities (Badura 2003; Latałowa et al. 2007). The information obtained from the oldest written sources has supplemented the archaeobotanical list of plants used by the citizens of Gdańsk (Badura et al. 2015; Badura and Możejko 2019). The large number of sampling sites has made it possible to compare the plant foodstuffs used by people of differing social status and in various historical periods (Badura et al. 2005; Badura 2011). An important part of the archaeobotanical research in Gdańsk was the comparison of the data on the use of plants, the importance of foodstuffs and the trade in plant products with similar records from other towns of northern Poland (Badura et al. 2004) and the Hanseatic cities of northern Europe (Latałowa et al. 2007; Karg et al. 2007; Latałowa et al. 2009a).

Sampling of sediment profiles including both natural and cultural layers and application of different methods (pollen analysis including NPPs, macrofossil analysis, geochemistry and radiocarbon dating), have enabled a comprehensive reconstruction of the natural history of Gdańsk. The data have allowed us to describe the natural and human environmental changes in the period preceding the foundation of the earliest medieval settlement and then during the early stages of the development of the town (Latałowa et al. 2009b; Święta-Musznicka et al. 2011; Święta-Musznicka and Latałowa 2016). Information on environmental changes around the town has been obtained from the Gołębiewo pollen site, Wysoczyzna Gdańska (“Gdańsk Upland”) (Fig. 1b) (Pędziszewska and Latałowa 2016).

The main aim of this review paper is to summarize the most important results of the research that has been done over many years on the natural conditions of settlement in the area of the oldest districts of Gdańsk from ca. the 5th until the end of the 14th centuries. The paper is based on both previously published data and new results, assembling information on local environmental diversification caused by the spatial development of the town, changes in local vegetation and the living conditions of people in the developing town and their use of plants (Table 1).

\section{Location and development of medieval Gdańsk}

Gdańsk (54 21' 07" N; $18^{\circ} 38^{\prime} 46^{\prime \prime} \mathrm{E}$ ) developed at the river mouth of the Wisła (Vistula), near the Gulf of Gdańsk in the Baltic Sea (Fig. 1a). The area is dissected by several smaller rivers, branches of the Wisła or flowing from the morainic upland to the sea. In the past they formed a complex hydrological network which has not been fully examined to this day, mostly due to the strong changes to it over the centuries. The first settlements identified by archaeologists in the oldest parts of the town developed on sandy alluvial fans lying within the extensive wetland (Zbierski 1978a; Paner 2015). 
Fig. 1 Location of the study area and sites. a position of Gdańsk in northern Europe; b location of Gołębiewo I pollen site and Grodzisko stronghold, and the area of Gdańsk covered by the archaeobotanical investigation; $\mathbf{c}$ location of archaeobotanical sites. The orange dots indicate positions of sites in Old Town, red dots in Main Town and green dots on Granary Island. $\mathrm{M}$, sites with macrofossil data; $\mathrm{M}+\mathrm{P}$, sites with macrofossils, pollen and NPP data. Contour map after Niecikowski 2016; mid 16th century plan of Gdańsk after Paner 1999a

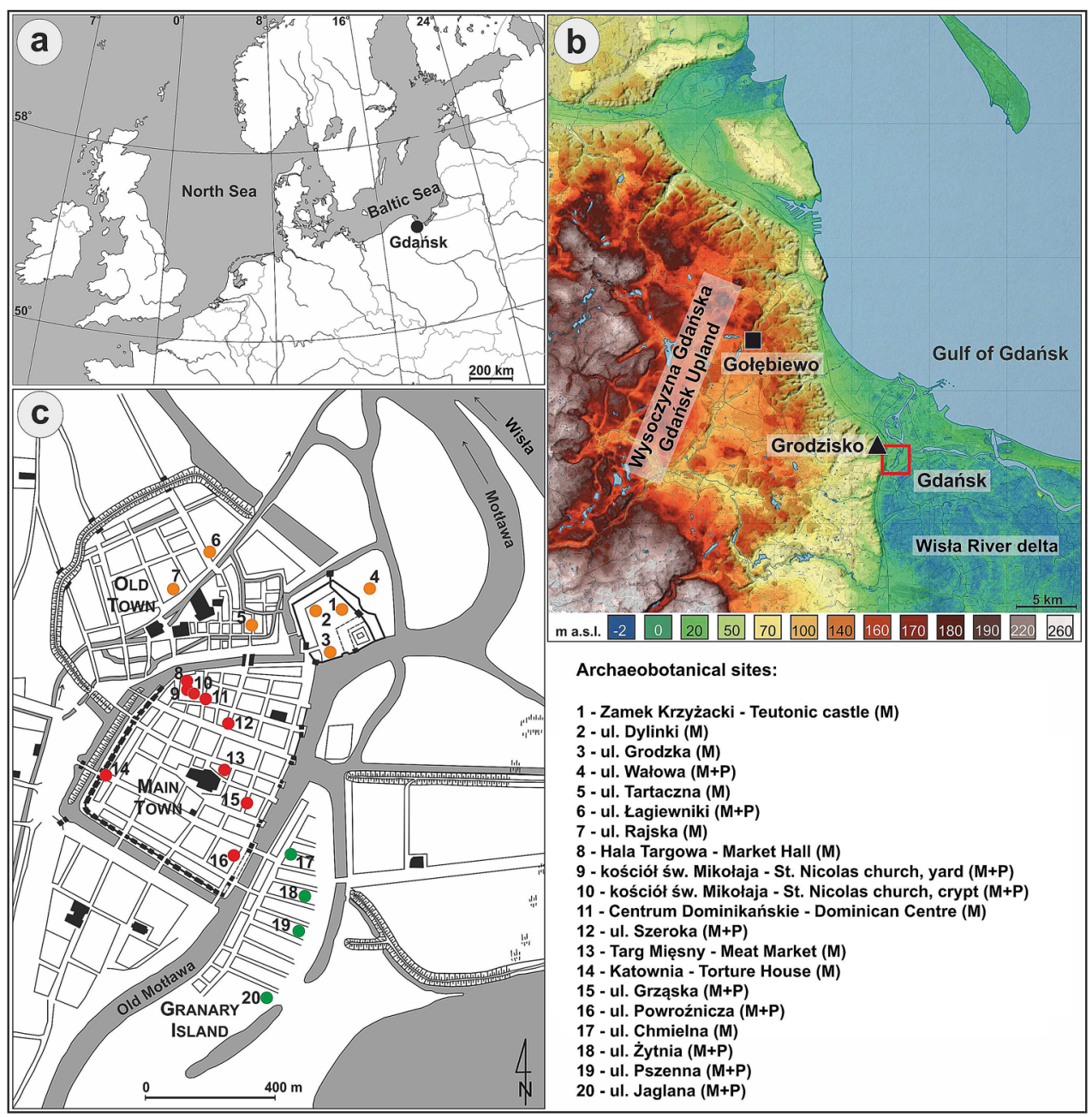

To the west, Gdańsk borders with the Pojezierze Kaszubskie ("Kashubian Lakeland") which was the agricultural base for the town and a source of timber over the centuries. The diversity of the local environment with different kinds of natural resources, including amber, was certainly an important factor in the economic success of Gdańsk. The latest historical research shows that the origins of Gdańsk are related to the growth in economic importance of the area stretching along the Gulf of Gdańsk in the late 9th and the early 10th centuries (Śliwiński and Możejko 2017). The oldest stronghold of Gdańsk, now known as Grodzisko on Gradowa Góra, was a 10th century watchtower constructed on the hill above the low-lying floodplain of the rivers Motława and Wisła (Fig. 1b). In the mid 11th century, it was moved to the area where the Motława joined the Wisła at the time (Śliwiński and Możejko 2017). Here, on a small island, a new stronghold and settlement developed, which attracted craft workers, merchants and fishermen; it is here that the archaeological excavations were started in the 1950s (Jażdżewski 1955a, b), accompanied by the first archaeobotanical work (Lechnicki 1955; Lechnicki et al. 1961).
Stare Miasto (“Old Town”) provides scarce evidence of settlement activity in the 10th and 11 th centuries, but by the 12 th and 13 th centuries, settlement here was already intensive (Paner 2015). Several mills were established here, with Wielki Młyn ("Great Mill”) built in AD 1350, thought to have been the largest industrial building in medieval Europe (Kochanowski 1998). Old Town was also a location for the Teutonic castle, built in the 15 th century on the site of the earlier seat of the local knights and totally destroyed in the 15 th century by the citizens of Gdańsk (Śliwiński and Możejko 2017).

Główne Miasto ("Main Town”) is a later part of Gdańsk, where vigorous development took place as late as the 14th century in a partly waterlogged area that needed extensive work before it was settled (Maciakowska 2011). Main Town opens to the river Motława with several gates connecting the town with the port.

Wyspa Spichrzów ("Granary Island") is an artificial island lying between the channels of the Motława. In the 16 th century, the former moat separating this area from the mainland was deepened and widened to create a new river 
Table 1 Archaeobotanical sites used in the study. Site numbers as in Fig. 1

\begin{tabular}{|c|c|c|c|c|c|}
\hline Site No. & Site name & Sediment type & Type of data & Date (century AD) & Publication(s) \\
\hline 1 & $\begin{array}{l}\text { Zamek Krzyżacki } \\
\text { (Teutonic castle) }\end{array}$ & $\begin{array}{l}\text { Limnic sediments, } \\
\text { cultural layers }\end{array}$ & $\begin{array}{l}\text { Macrofossils, } \\
\text { historical } \\
\text { documents }\end{array}$ & 13 th & $\begin{array}{l}\text { Możejko 2006; Badura et al. 2015; } \\
\text { Badura and Możejko 2019; } \\
\text { Jarosińska unpubl. }\end{array}$ \\
\hline 2 & ul. Dylinki & Cultural layers & Macrofossils & $11 / 12$ th, 12th & $\begin{array}{l}\text { Mądalski 1952; Moldenhawer 1952; } \\
\text { Lechnicki 1955; Lechnicki et al. } \\
\text { 1961; Badura 2011 }\end{array}$ \\
\hline 3 & ul. Grodzka & $\begin{array}{l}\text { Limnic sediments, } \\
\text { peat deposits, } \\
\text { cultural layers }\end{array}$ & Macrofossils & $\begin{array}{l}\text { 10-11th, 10/11th, 11th, } \\
\text { 11-12th }\end{array}$ & $\begin{array}{l}\text { Badura 2011; Święta-Musznicka } \\
\text { unpubl. }\end{array}$ \\
\hline 4 & ul. Wałowa & $\begin{array}{l}\text { Limnic sediments, } \\
\text { peat deposits }\end{array}$ & $\begin{array}{l}\text { Macrofossils, } \\
\text { pollen, NPPs }\end{array}$ & 12th, 13th, 14th & $\begin{array}{l}\text { Święta-Musznicka and Pińska unpubl.; } \\
\text { Święta-Musznicka unpubl. }\end{array}$ \\
\hline 5 & ul. Tartaczna & Cultural layers & Macrofossils & 12 th, 12/13th, 13th & Badura unpubl. \\
\hline 6 & ul. Łagiewniki & $\begin{array}{l}\text { Limnic sediments, } \\
\text { peat deposits }\end{array}$ & $\begin{array}{l}\text { Macrofossils, } \\
\text { pollen, NPPs }\end{array}$ & $<10$ th, 10th, 11th & $\begin{array}{l}\text { Święta-Musznicka et al. 2011; Święta- } \\
\text { Musznicka unpubl. }\end{array}$ \\
\hline 7 & ul. Rajska & Cultural layers & Macrofossils & 14 th & Badura 2010; Badura unpubl. \\
\hline 8 & $\begin{array}{l}\text { Hala Targowa } \\
\text { (Market Hall) }\end{array}$ & Cultural layers & Macrofossils & $\begin{array}{l}\text { 11th, 12/13th, 11-12th, } \\
\text { 12th, 12/13th }\end{array}$ & Badura 2011; Badura unpubl. \\
\hline 9 & $\begin{array}{l}\text { kościół św. } \\
\text { Mikołaja (St. } \\
\text { Nicholas church)- } \\
\text { yard }\end{array}$ & Cultural layers & $\begin{array}{l}\text { Macrofossils, } \\
\text { pollen, NPPs }\end{array}$ & 12 th, 13 th & $\begin{array}{l}\text { Święta-Musznicka et al. 2013; Święta- } \\
\text { Musznicka, Badura, Latałowa unpubl. }\end{array}$ \\
\hline 10 & $\begin{array}{l}\text { kościół św. } \\
\text { Mikołaja (St. } \\
\text { Nicolas church) - } \\
\text { crypt }\end{array}$ & Cultural layers & $\begin{array}{l}\text { Macrofossils, } \\
\text { pollen, NPPs }\end{array}$ & 13 th & $\begin{array}{l}\text { Święta-Musznicka et al. 2013; Święta- } \\
\text { Musznicka, Badura, Latałowa unpubl. }\end{array}$ \\
\hline 11 & $\begin{array}{l}\text { Centrum } \\
\text { Dominikańskie } \\
\text { (Dominican } \\
\text { Centre) }\end{array}$ & Cultural layers & Macrofossils & $\begin{array}{l}10 / 11 \text { th, } 11 \text { th, } 11 / 12 \text { th, } \\
\text { 12th, 12/13th, 13th, } \\
13 / 14 \text { th, 14th }\end{array}$ & $\begin{array}{l}\text { Badura 2011; Badura and Jarosińska } \\
\text { unpubl. }\end{array}$ \\
\hline 12 & ul. Szeroka & Peat deposits & $\begin{array}{l}\text { Macrofossils, } \\
\text { pollen, NPPs }\end{array}$ & $<10$ th, 10-12th, 13th & Święta-Musznicka unpubl. \\
\hline 13 & $\begin{array}{l}\text { Targ Mięsny } \\
\text { (Meat Market) }\end{array}$ & Cultural layers & Macrofossil & 14 th & Badura and Latałowa 2018 \\
\hline 14 & $\begin{array}{l}\text { Katownia } \\
\text { (Torture House) }\end{array}$ & Cultural layers & Macrofossils & 14 th & Badura and Latałowa 2016 \\
\hline 15 & ul. Grząska & $\begin{array}{l}\text { Limnic sediments, } \\
\text { peat deposits, } \\
\text { cultural layers }\end{array}$ & $\begin{array}{l}\text { Macrofossils, } \\
\text { pollen, NPPs }\end{array}$ & $\begin{array}{l}<10 \text { th, } 10-12 \text { th, } 13 \text { th } \\
\text { 14th }\end{array}$ & $\begin{array}{l}\text { Badura 2011; Święta-Musznicka et al. } \\
\text { 2011; Święta-Musznicka and } \\
\text { Jarosińska unpubl. }\end{array}$ \\
\hline 16 & ul. Powroźnicza & $\begin{array}{l}\text { Peat deposits, } \\
\text { cultural layers }\end{array}$ & $\begin{array}{l}\text { Macrofossils, } \\
\text { pollen, NPPs }\end{array}$ & 13th, 13-14th, 14th & $\begin{array}{l}\text { Badura 2011, Święta-Musznicka } \\
\text { unpubl. }\end{array}$ \\
\hline 17 & ul. Chmielna & Cultural layers & Macrofossils & 14 th & Badura 2011 \\
\hline 18 & ul. Żytnia & $\begin{array}{l}\text { Limnic sediments, } \\
\text { peat deposits, } \\
\text { cultural layers }\end{array}$ & $\begin{array}{l}\text { Macrofossils, } \\
\text { pollen, NPPs }\end{array}$ & $\begin{array}{l}<10 \text { th, } 10-12 \text { th, } 13 \text { th } \\
14 \text { th }\end{array}$ & $\begin{array}{l}\text { Święta-Musznicka et al. 2011; Święta- } \\
\text { Musznicka and Latałowa 2016; } \\
\text { Święta-Musznicka unpubl. }\end{array}$ \\
\hline 19 & ul. Pszenna & $\begin{array}{l}\text { Limnic sediments, } \\
\text { peat deposits, } \\
\text { cultural layers }\end{array}$ & $\begin{array}{l}\text { Macrofossils, } \\
\text { pollen, NPPs }\end{array}$ & $\begin{array}{l}<10 \text { th, } 10-12 \text { th, } 13 \text { th } \\
13-14 \text { th, 14th }\end{array}$ & $\begin{array}{l}\text { Święta-Musznicka and Latałowa 2016, } \\
\text { Święta-Musznicka unpubl. }\end{array}$ \\
\hline 20 & ul. Jaglana & Limnic sediments & $\begin{array}{l}\text { Macrofossils, } \\
\text { pollen, NPPs }\end{array}$ & $<10$ th & $\begin{array}{l}\text { Święta-Musznicka et al. 2011; Święta- } \\
\text { Musznicka and Latałowa 2016; } \\
\text { Święta-Musznicka unpubl. }\end{array}$ \\
\hline
\end{tabular}

channel, improving the flow of traffic within the port of Gdańsk and extending access to the wharves. This floodplain wetland started to be used for granaries and as a storage area in the 13th century, but by the end of the 14th century there were already some 120-130 granaries (Kaczyńska et al. 2005).

In the 11th-14th centuries Gdańsk was a rapidly growing centre which attracted merchants, craft workers and 
Table 2 Chronological distribution of samples used in the study according to the context/feature type; "other" represents embankment fills, vessel contents or storage pits

\begin{tabular}{|c|c|c|c|c|c|c|c|c|c|c|c|}
\hline \multirow[t]{2}{*}{ Context/feature type } & \multicolumn{11}{|c|}{ Chronology of the samples (century) } \\
\hline & 5-10th & $10 / 11$ th & 11th & $11 / 12$ th & $10-12$ th & 12 th & $12 / 13$ th & 13th & 13/14th & 14th & Sum \\
\hline Limnic and peat sediments & 92 & 7 & 4 & 3 & 20 & 1 & & 13 & 3 & 9 & 152 \\
\hline Yards & & 1 & & & & & 3 & 2 & & 14 & 20 \\
\hline Houses & & & 6 & & & 4 & 31 & & & 2 & 43 \\
\hline Latrines & & & & & & & & & & 5 & 5 \\
\hline Refuse heaps & & & 3 & & & & 1 & & & & 4 \\
\hline Granaries & & & & & & & & & & 25 & 25 \\
\hline Undefined useful layers & & 3 & 2 & 4 & & 21 & 4 & 36 & 2 & 29 & 101 \\
\hline Leveling & & & & & & & & & 1 & 6 & 7 \\
\hline Moat backfills & & & & & & & & & & 3 & 3 \\
\hline Other & & & 8 & & & 1 & & & & 2 & 11 \\
\hline Sum of samples & & & & & & & & & & & 371 \\
\hline
\end{tabular}

sailors of various nationalities, but also the scene of armed conflicts causing destruction of the town. Religious orders established there, building churches and monasteries together with their associated mills, gardens and other facilities. In the mid- 13 th century Gdańsk received its charter as a town according to Lübeck law. In the early 14th century, Old Town was partially destroyed by the Teutonic Knights, who then established a commander's office and built a castle here. At that time, in the area of the Main Town, a new urban centre was located according to Chełmno (Kulm) law, which defined relations between the burghers and the Teutonic Order and established the rights for shipping and river crossing on the Wisła. These regulations later covered the whole area of Gdańsk, however failing to avert fighting, which erupted periodically. In AD 1361, the town became a member of the Hanseatic League (Śliwiński and Możejko 2017).

\section{Site locations, materials and methods}

The data presented in this paper are based on the results of archaeobotanical investigations in 20 sites situated in the area of the oldest districts of Gdańsk, Old Town, Main Town and Granary Island and the Gołębiewo pollen site (Fig. 1c, b, Table 1).

Within the projects completed in 1998-2015, botanical samples were collected from various archaeological features and cultural layers within individual excavation areas or in a form of profiles taken directly from the trench walls. At ten sites, limnic sediments and peat beneath the cultural layers were also collected, with an Instorf sampler. Macrofossils were analysed from 371 samples, more than $40 \%$ of which (152) were limnic sediment and peat, whereas 219 samples were collected from archaeological features or cultural layers (Table 2). The plant remains were mainly waterlogged, and they were mostly very well preserved thanks to the high ground water table in the town. Mineralised remains were scarce. Purely charred material was collected only from granaries. The methodology for the sample collection strategy and laboratory preparation and treatment for macrofossil analysis have been thoroughly described in earlier publications (Latałowa et al. 2007; Badura 2011; Święta-Musznicka et al. 2013). Detailed information on the qualitative and quantitative content of the botanical samples has been archived in the ARCHBOT-UGDA DATABASE in the Laboratory of Palaeoecology and Archaeobotany, University of Gdańsk. The results presented in this paper have been supplemented with the data from extensive work on the early medieval settlement at site 2, ul. Dylinki (street) (Fig. 1c) (Mądalski 1952; Moldenhawer 1952, 1953; Lechnicki 1955; Klichowska 1959; Lechnicki et al. 1961). However, due to different methodologies applied then, the publications lack information on sample volumes and record the number of specimens and frequency of taxa inconsistently, so these data cannot be fully compared with the recent results. We use them to calculate the number of taxa in particular groups of useful plants for particular centuries.

Pollen and NPP analysis was done on 230 samples from ten sites in different parts of the town (Fig. 1c). The methods used 


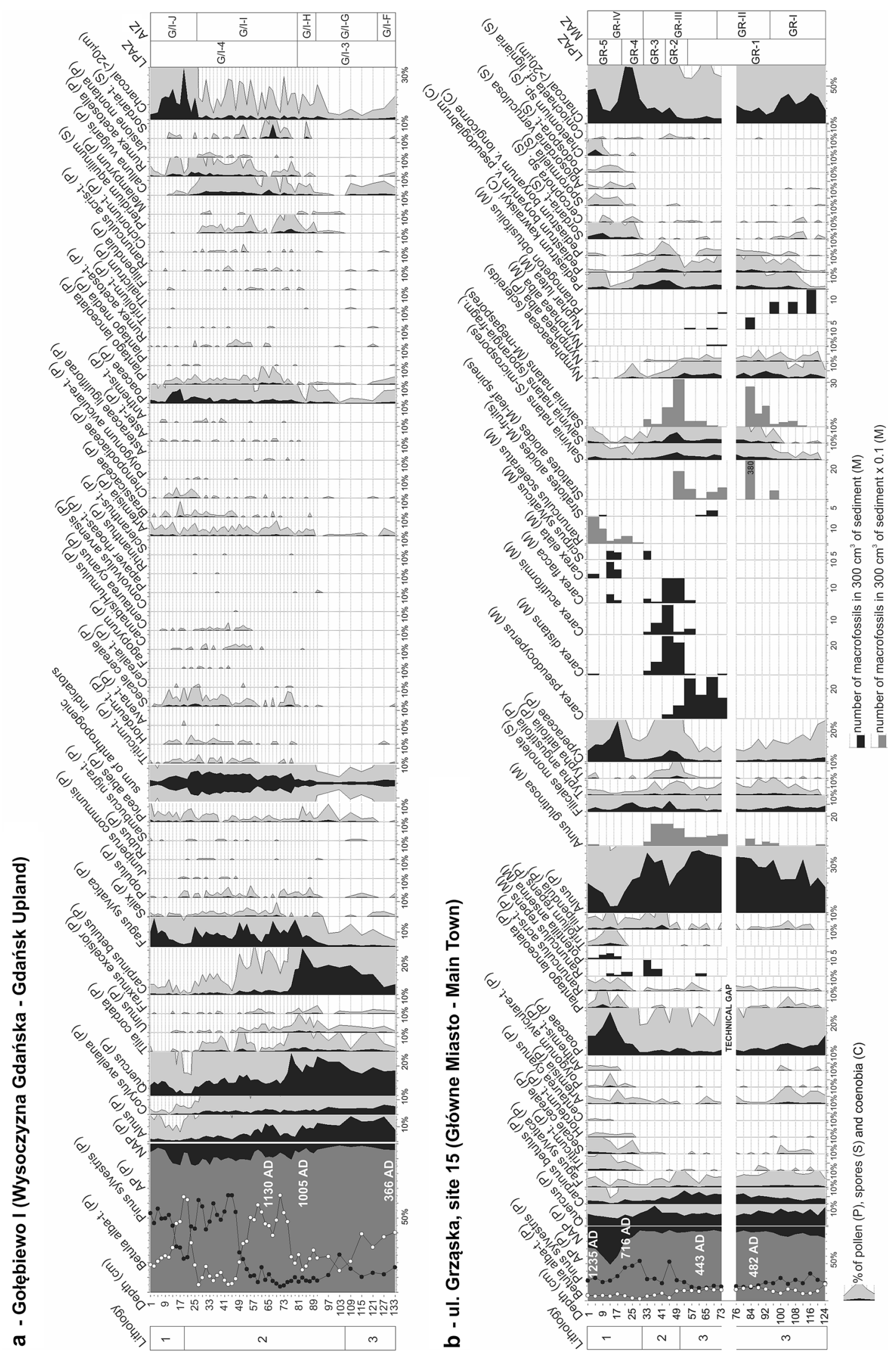


४Fig. 2 a Simplified pollen diagram from Gołębiewo I; lithology, 1, Sphagnum peat; 2, Sphagnum-Eriophorum peat; 3, Sphagnum peat with variable proportion of Eriophorum sp. and Ericaceae (after Pędziszewska and Latałowa 2016). b simplified pollen and macrofossil diagram from site 15; lithology, 1, herbaceous peat with high proportion of silt and charcoal; 2, herbaceous peat with detritus gyttja, silt, sand and wood; 3, silt with detritus gyttja and fine sand (after Święta-Musznicka unpubl.). LPAZ, local pollen assemblage zones; AIZ, anthropogenic indicator zones; MAZ, macrofossil assemblage zones

for pollen analysis have been described in earlier publications (Święta-Musznicka et al. 2011, 2013).

The chronostratigraphy is based on the archaeological and dendrochronological dating provided by archaeologists responsible for particular sites and AMS radiocarbon dating done on 45 samples in the Poznań Radiocarbon Laboratory and calibrated with OxCal v. 4.3.2 (Bronk Ramsey 2017). The IntCal13 age calibration curve was used for calculating the calendar age ranges and the medians used in the present paper (Reimer et al. 2013). The radiocarbon dates for particular sites have been published (Latałowa et al. 2009b; ŚwiętaMusznicka et al. 2011, 2013; Święta-Musznicka and Latałowa 2016). The new chronology based on recent dendrochronological research (Kościński and Paner 2005) has been used for the data originally published in the 1950s and 60s from site 2 .

The botanical nomenclature follows (Mirek et al. 2002).

\section{Results and discussion}

\section{Material richness}

The great diversity of the sources of the botanical material and its perfect preservation has ensured a broad representation of useful plants and taxa typical of both natural habitats and those resulting from human occupation. Full macrofossil data from Gdańsk, archived in the ARCHBOT-UGDA DATABASE, provide information on 479 plant taxa including 370 species and subspecies. Among them, 127 taxa represent weeds which would have grown in cultivated fields, gardens and in various kinds of ruderal habitats (ESM Table 1). The list of crop plants and other useful plants includes 76 taxa (ESM Table 2). At some sites, remains of plants typical of natural and seminatural vegetation and of aquatic habitats were common. Remains of aquatic fauna, such as Porifera, Ostracoda, Cladocera (Daphnia sp.), Turbellaria, Hirudinea, Bryozoa (Cristatella mucedo, Lophopus cristallinus, Plumatella sp.), molluscs and fish occurred abundantly at several sites (Święta-Musznicka and Latałowa 2016). The palynological samples from Gdańsk are characterised by high taxonomic richness as well. We identified 182 taxa of trees, shrubs and herbs and 74 NPP taxa, mainly green algae and coprophilous fungi (Fig. 2b; Święta-Musznicka et al. 2013; Święta-Musznicka and Latałowa 2016).

\section{Natural conditions before the development of the town}

One of the most interesting issues in studies into the origins and development of ancient urban centres is the role of environmental factors in deciding on the location of a town and their affect on its further development. Among the most important factors in determining the development of European towns in the Middle Ages was an easily defended site and a transport network for trade. Thus, the location of Gdańsk within the forks of the rivers fulfilled both these conditions.

Availability of food and other natural resources and also potential for development of the rural surroundings of a growing town were of prime importance too (Molaug 2010). In Gdańsk, besides the sea and rivers providing excellent possibilities for fishery, a variety of woodlands was another attractive factor providing game and a range of useful materials, including wood - a product of prime importance for the developing town. The pollen data (Fig. 2a) show that from around the 5th to the 10th century the upland landscape formed by moraines around Gdańsk was mainly covered by broadleaved woodlands of Quercus sp. and Carpinus betulus, with some Corylus avellana, Tilia cordata, Ulmus sp., Fagus sylvatica and Pinus sylvestris. In river valleys and along watercourses, patches of alder-elm woodlands were common. The low-lying areas which would later be incorporated into the expanding town were also mainly wooded. Both pollen and macrofossil data confirm that alder woods were widespread here, while small patches of mixed deciduous woods would have grown on the scattered mineral outcrops (Figs. 2b, 3).

In the pollen diagrams from Gdańsk itself, the proportions of arboreal pollen (AP) vary between 58 and $83 \%$, but the non-arboreal pollen (NAP) represents mostly wetland environments indicating the presence of vegetation of shallow water bodies and marshes typical of a floodplain. High proportions of aquatic plant remains, like Salvinia natans, Stratiotes aloides, Nymphaea alba, Lemna trisulca, Potamogeton perfoliatus, Nuphar lutea or Ceratophyllum demersum, and of animal remains (Turbellaria, Porifera and Daphnia), are indicative of meso- or eutrophic stagnant or slow-flowing water (Figs. 2b, 3, 4). The remains of Pediastrum kawraiskyi, P. boryanum v. pseudoglabrum and Gloeotrichia are evidence of short-lived blooms of green algae and cyanobacteria. These results, and those of geochemical analyses (Święta-Musznicka and Latałowa 2016), confirm the high trophic level and occasional oxygen depletion in the aquatic environment. 


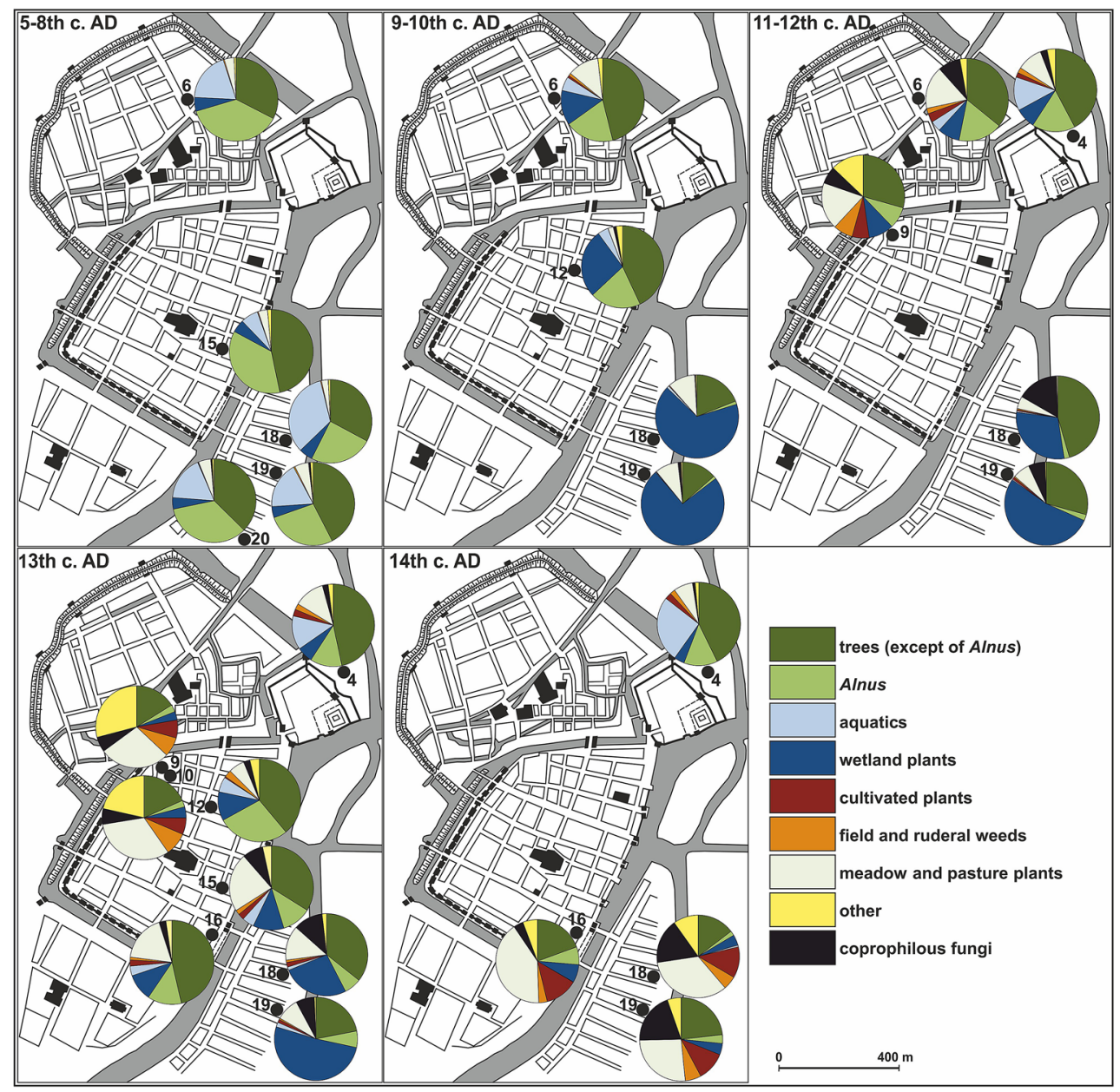

Fig. 3 Pie diagrams showing the average proportions of pollen taxa representing selected environments and cultivated plants in Gdańsk in consecutive periods from the 5 th to the 14th century. Site numbers as in Fig. 1c and Table 1

A significant change in the local environment took place around the 9th-10th centuries. The palaeoecological data illustrate a considerable lowering of the water table in the wetland. In the studied profiles, the aquatic indicators are replaced by taxa typical of mires (Figs. 2b, 3, 4). This change left a distinct signature in several profiles in a form of hiatuses occurring at the transition between limnic sediments and peat (Święta-Musznicka and Latałowa 2016). A sharp decline in the proportion of Alnus pollen in some sites, or its distinctly lower frequency in others (Fig. 3), indicate a great reduction of the alder woods at that time. As a result, an open marsh vegetation with ferns (Thelypteris palustris, Filicales monolete), Scirpus sylvaticus, Carex pseudocyperus, C. distans, Menyanthes trifoliata and others spread over the area (Figs. 2b, 4). These ecological processes agree well with the data on climatic changes around the 9th-10th centuries from the Medieval Climate Anomaly, including longlasting droughts (Helama et al. 2009; Büntgen et al. 2011) and a widespread Alnus decline most probably caused by a sequence of climatic events detrimental to alder followed by a pathogen attack (Stivrins et al. 2017; Latałowa et al. 2019).

\section{The beginnings of the medieval settlement}

According to the pollen diagram from Gołębiewo, a rise in settlement activity and woodland disturbances around Gdańsk started in the 10th century (Fig. 2a; Pędziszewska and Latałowa 2016). The data suggest that especially at the edges of the upland, the loss of woodland at the time resulted mainly from the demand for oak timber, which was the basic building material for the emerging strongholds. In turn, the pollen data from the area where Gdańsk developed suggest that there was still very limited human activity there in the 10th century (Figs. 2b, 3). The results corroborate well with the archaeological and historical data (Śliwiński 2009; Paner 2015).

A significant decrease in tree pollen, mainly of Carpinus and Quercus, and a rise in herb pollen indicate a reduction of woodland around AD 1030 (Fig. 2a). The demand for 


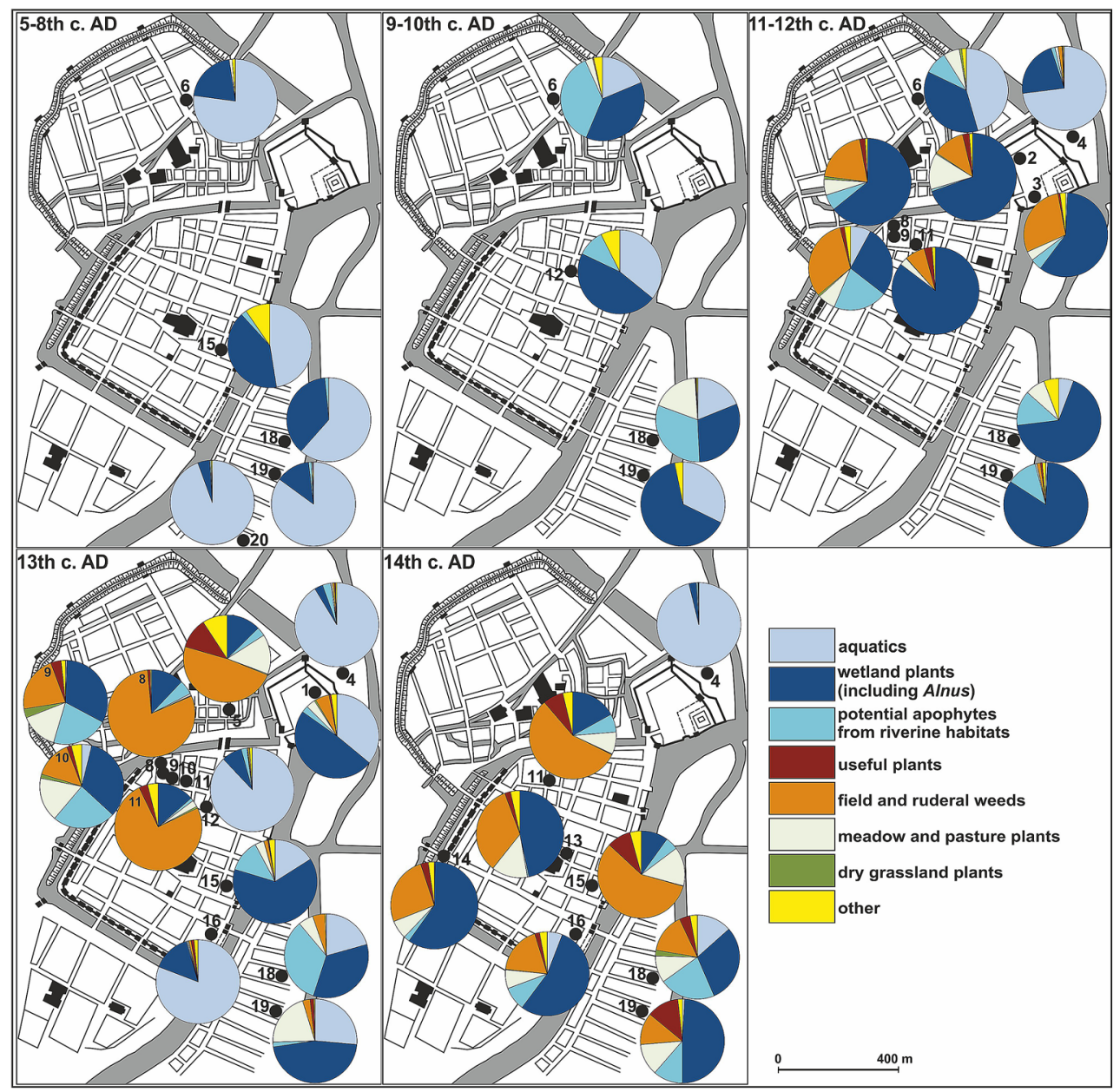

Fig. 4 Pie diagrams showing the average proportions of macrofossils representing selected environments and useful plants in Gdańsk in consecutive periods from the 5th to the 14th century. Site numbers as in Fig. 1c and Table 1

timber, especially oak, for building in the town must have increased at the time (Kościński and Paner 2005). In the woodland clearings, secondary woods with Betula and Pinus and then Fagus grew up where the farmland was not used. Beech, despite human pressure, expanded vigorously in the local woods and replaced hornbeam and oak. The higher land was increasingly used for farming, as demonstrated by the increase of the pollen of Secale, Triticum-type and Hordeum-type together with cornfield weeds and plants of meadows and pastures, like Poaceae, Plantago lanceolata, $P$. media, Ranunculus acris-type and the remains of coprophilous fungi (Sordaria-type).

In the 10th century, in most of the low-lying land around Gdańsk, alder wetland woods and water bodies were replaced by open fens and wet meadows (Fig. 3) with Filipendula ulmaria, Potentilla anserina and Ranunculus repens, which were then used for grazing (Fig. 2b) as suggested by the considerable proportion of coprophilous fungi, like Sordaria-type and Sporormiella (Davis and
Shafer 2006; Florenzano et al. 2013). The palynological data illustrate the first increase of settlement activity in this area around the early 11th century (Fig. 3), which agrees with the archaeological data (Paner 2015). The droughts which lowered the water table in wetland habitats could have been a stimulating factor for local settlement development in areas too wet to have been colonised earlier, even though there was already some settlement in the region (Śliwiński 2009). The dying wetland alder woods were probably used as a source of timber to build Gdańsk. According to Zbierski (1978b), alder wood accounted for about $19 \%$ of all the building timber used in the 11th century.

\section{Environmental changes during the expansion of Gdańsk}

The palaeoecological records suggest a very varied environment in the early period of settlement, and similar to other early medieval urban contexts (Kozáková et al. 2009), with 
a mosaic of different vegetation types (Figs. 3, 4). Pollen spectra dated to the 11th-12th centuries are marked by a high proportion of Pinus pollen, with low values from other trees (Fig. 2b). We suggest an over-representation of pine pollen due to loss of the local alder woods which had been an effective barrier to regional pollen transport. The increasing openness of the landscape facilitated pollen transfer from pine woods growing on sandbars stretching along the sea coast and from the surrounding uplands, where at that time pine expanded rapidly in the disturbed woodlands (Fig. 2a).

In the period between the 11th and 14th centuries, although the water table became distinctly lower, at several sites spread over the Old and Main Town, at least temporary shallow water-bodies with stagnant or slow-flowing water still existed as a part of a rich hydrological network (Figs. 3, 4). Such conditions persisted until the 14th century, notably in the north-eastern part of the area (site 4) where a dense network of moats and canals surrounded the castle of the Teutonic Order (Maciakowska 2015). Our studies beneath kościół św. Mikołaja (St. Nicolas church) built in the 14th-15th centuries (sites 9 and 10) also corroborated the presence of stagnant or slow-flowing water still there in the 12th-13th centuries (Święta-Musznicka et al. 2013). Aquatic vegetation consisted of Myriophyllum verticillatum, Nymphaea alba, Alisma plantago-aquatica, Lemna trisulca, Stratiotes aloides, Salvinia natans and Potamogeton spp., and algae including Pediastrum kawraiskyi, P. boryanum and Botryococcus spp. Among the aquatic fauna, species from Daphnia, Ostracoda and Porifera were common (Figs. 3, 4).

Wetland alder stands as well as open fens were significant in the Gdańsk landscape until the 14th century. In the 11th-12th centuries, fragments of alder wood were still present in the surroundings of the Teutonic castle (site 1) and in both the Old and Main Town, while in the area that later became Granary Island, the proportion of alder was much lower at the time and there were mainly open fens. A relatively high content of Alnus pollen (28\%) was recorded at site 12 in the 13th century, although contemporary samples from the nearby sites nine and ten contained very little alder pollen, indicating a difference in the local vegetation cover (Fig. 3). The macrofossil data provide evidence of the widespread, rich flora typical of floodplain habitats and a changing water-table, with Iris pseudacorus, Typha sp., various Juncus and Carex species, wet meadows with Caltha palustris, Menyanthes trifoliata, Ranunculus sceleratus, $R$. flammula, $R$. repens, Filipendula ulmaria, Lythrum salicaria and Lychnis flos-cuculi, and tall herbs typical of vegetation along river banks with Urtica dioica, Bidens cernua, B. tripartita, Polygonum hydropiper etc.

Although the main environments were wetlands, patches of dry land in the form of sandy alluvial fans occurred in a few places, as shown by both the reconstructions of the topography (Zbierski 1978a) and our study of the vegetation in the area around sites 9 and 10, where traces of the oldest settlement dated to the 10th century have been found (Gołembnik 2009). The archaeobotanical material from the area, dated to the 12th century, was rich in the pollen of crops, field and ruderal weeds as well as of meadow plants (Fig. 3). Surprisingly, the macroremains of Calluna vulgaris, Jasione montana, Rumex acetosella, Hypericum perforatum, Potentilla argentea and Arenaria serpyllifolia - species typical of dry grasslands, also occurred abundantly here, while they have been not recorded from any other site. This sandy alluvial fan next to an adjoining stream and surrounded by wetland meadows must have been favourable for settlement (Święta-Musznicka et al. 2013).

As the urban area expanded, a number of indigenous plants typical of riverside habitats rich in nutrients, such as Urtica dioica, Chenopodium album, Artemisia sp., Polygonum spp., Bidens cernua, B. tripartita and Galium aparine, spread there and formed the local ruderal vegetation of apophytes (native plants growing in anthropogenic habitats). The ruderal plant communities were also enriched by several nitrophilous archaeophytes (alien wild plants introduced up to the end of the 15th century) by then already established in the regional flora, like Chenopodium hybridum, Conium maculatum, Urtica urens and Descurainia sophia (Fig. 5, ESM Table 1). The pollen data demonstrate an increasing share of plants typical of trampled pathways like Polygonum aviculare and Plantago major as well (Fig. 2b). The list of various groups of weeds is substantial (ESM Table 1). The increasing number of weed taxa from the 10th/11th century transition to the 12th century (Fig. 5) reflects not only the spread of the local ruderal flora but also increasing transport of crops to the port and town (cf. Paner 1999b) and most probably the development of local gardening, as shown by records of archaeophytes (Ar) and apophytes (Ap1) in Fig. 5a. In turn, the many ruderal weeds (Fig. 5b) including apophytes typical of meadows and pastures (Ap2 in Fig. 5a) in the 12th century and their subsequent decline, might reflect changes in the layout of the town as it developed, causing alterations to the character of the local flora due to the expansion and higher density of the built-up area.

\section{Living conditions in the developing town}

The location of Gdańsk in a large wetland, in the fork between the rivers Wisła and Motława, with only a few drier places on alluvial fans, was a major challenge for the developing town. As already mentioned above, and as has been argued in earlier papers (Święta-Musznicka and Latałowa 2016; Latałowa et al. 2019), we suggest that the persistent droughts which occurred in the 9th-10th centuries finally made the wetland accessible for the local settlement. The 
Fig. 5 Changes in the anthropogenic flora in medieval Gdańsk. a number of archaeophytes as crop weeds (Ap1) and other apophytes (Ap2); b number of and flax crops and those of root crops, gardens and ruderal habitats. For the list of taxa and (Ar), apophytes growing mainly weed taxa most typical of cereal classifications, see ESM Table 1

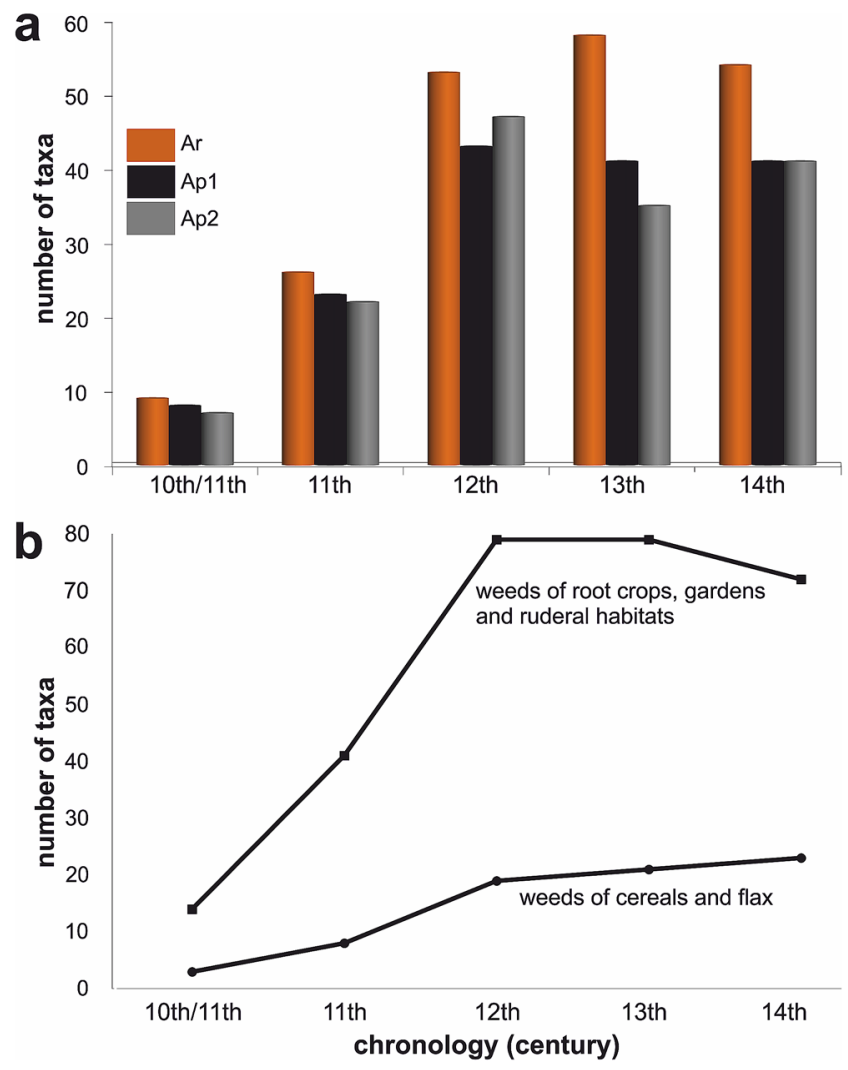

earliest settlements developed on small patches of mineral soil from the alluvial fans, but then gradually spread on to muddy and peaty ground. This is well illustrated by the archaeobotanical data which still show a large proportion of wetland vegetation and aquatic environments in the 13th century in the northeast of the city (Fig. 4). Notably, the political and economic pressure at the beginning of the 14 th century resulted in a vigorous expansion of the town (Paner 2015; Śliwiński and Możejko 2017). The builders had to contend with a high water table and unstable ground (Maciakowska 2011). The archaeological investigations have uncovered levelling and insulation layers up to $2 \mathrm{~m}$ deep built up of reeds, tree branches and chopped wood fragments on Granary Island (Kaczyńska et al. 2005) and even thicker in other parts of the town (Maciakowska 2011). In some houses parts of old boats were also used as packing material beneath the floors of buildings (Krzywdziński 2009). The rising ground surface made frequent rebuilding necessary (Polak 2009). For example, in ul. Chlebnicka, the early medieval structures lie as much as $6.8 \mathrm{~m}$ below the presentday street level (Paner 2001). Most wooden houses and also the later ones of brick were built upon large wooden piles, mostly of oak, driven into the ground to stabilise them (Paner 2001; Krzywdziński 2009). Such a solution was even used for the foundations of the huge kościół Mariacki (St. Mary's church), the largest brick built church in medieval Europe. All the building works as well as large-scale drainage, regulation of watercourses and moats, and construction of a water supply system, resulted in a gradual decrease of the ground moisture in most of the city as shown by our archaeobotanical data (Figs. 3, 4; Maciakowska 2005).

The waterlogging favoured accumulation of organic waste. The gravity of the situation then is illustrated by one of the earliest known civil codes in Gdańsk from around AD 1460, listing various regulations for the maintenance of cleanliness and forbidding pollution of the waterway to the port, which was punishable by death (Paner 2004). Our geochemical data confirm enrichment of the local aquatic habitats with phosphorus and nitrogen, indicating a significant increase of these elements, especially phosphorus, since the 13th century (Święta-Musznicka and Latałowa 2016). A high phosphorus content in archaeological deposits is regarded as one of the most important indicators of human activities, including food processing and storage, waste disposal and burning of organic matter. It is also evidence of human and animal faeces at the sites (Wilson et al. 2008; Mercuri et al. 2010; Cook et al. 2014). In Gdańsk, abundance of dung is confirmed by the many remains of coprophilous fungi (including Sordaria-type, Sporormiella and Chaetomium sp.) and intestinal parasite eggs of Trichuris and Ascaris in the sediments dated to the 11th century and later (Święta-Musznicka et al. 2013; Święta-Musznicka and Latałowa 2016; Figs. 2b, 3). Insanitary conditions were a general problem in medieval towns in Europe (Ewert 2007). 
Fig. 6 Number of taxa in particular groups of useful plants known from medieval Gdańsk. The data are based on macroscopic plant remains, pollen and historical sources. The list of taxa and classification are in ESM Table 2

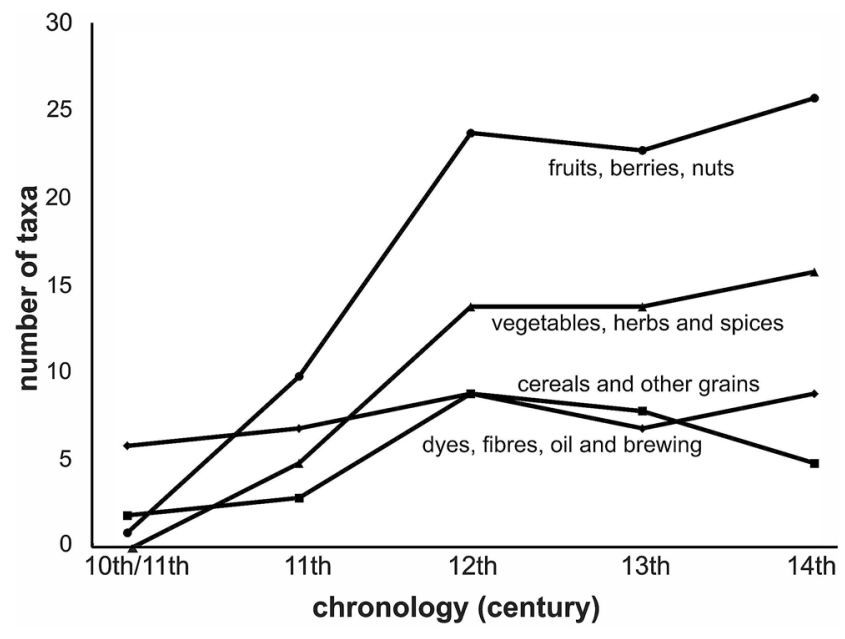

periods earlier than the 11th century are too scarce to be used for any conclusion. In general, the numbers of plant taxa used in Gdańsk gradually increased through time, with distinct peaks in the 12th and 14th centuries (ESM Table 2, Fig. 6). This must have been caused by the introduction of new products to the local market, following the development of the port and town in the 12th century enabling broader trade contacts (Paner 1999b) and then by the accession of Gdańsk to the Hanseatic League in the 14th century (Śliwiński and Możejko 2017). Another factor stimulating development of farming, gardening and introduction of new plant foods was the local establishment of the Cistercian and the Dominican monastic orders in the 12th and the 13th centuries respectively and then the foundation of the commander's office of the Teutonic Knights in the 14th century (Śliwiński and Możejko 2017).

The staple plant foods in medieval Gdańsk must have been cereals. The earliest, occasional finds of Panicum miliaceum, Secale cereale, Triticum aestivum and Hordeum vulgare were recorded in the samples dated to the 10th/11th century transition, collected from site 11. Avena sativa was recorded at two sites in the layers dated to the 12th century. The most exhaustive data come from the settlement at site 2 (Lechnicki 1955; Lechnicki et al. 1961; Badura 2011), where in the samples dated from the 11th century to the 12 th/13th century transition charred and uncharred remains of millet distinctly outnumbered those of other cereals, both in number of remains and frequency. This seems to be in line with other results from northwestern Poland, suggesting that millet was a major crop in the region during the early medieval period (Jarosińska 1994; Latałowa 1999; Badura et al. 2018). In the 13th century gradual development of Granary Island began and by the end of the 14th century 120-130 granaries already existed there (Paner 1999b). Historical and archaeobotanical data suggest that rye at that time was one of the most important crops delivered to Gdańsk from the region and 
from more distant areas in central and southern Poland (Zbierski 1978c; Latałowa et al. 2007; Badura et al. 2015). It was then sold to European markets, however some consignments from inland reached the local market. This is shown by the occurrence of cereal weeds such as Galium tricornutum which are typical of warm rendzina soils in southern Poland, seeds of which have been found not only at Granary Island, but also at other sites in Gdańsk (Latałowa et al. 2007; Badura 2011).

Apart from the remains of the main cereals, some other grain crops were also recorded. A few uncharred glumes of Setaria italica were found in the 12th century cultural layers at site 2 and from the 14th century samples at site 16, however, it is not clear if we are dealing here with the remains of a cultivated plant or a weed (Latałowa et al. 2007). The earliest scattered finds of Fagopyrum esculentum were found from a layer dated to the 12 th/13th century transition at site 8 and then at two other sites dated to the 14th century (Badura 2011). Oryza sativa appears on a list of goods in the 14th century inventory books of the Teutonic castle (Możejko 2006; Badura et al. 2015).

The use of some starchy wild plants in early medieval Gdańsk seems to be shown by the archaeobotanical data from site 2, where large concentrations of crushed Chenopodium album seeds in the settlement layers dated to the 12th-13th centuries must be remains from processing the seeds for food (Lechnicki 1955). There is ample data on the use of C. album as a food plant in prehistoric and early historic periods (Helbæk 1958, 1960; Behre 2008; MuellerBieniek et al. 2019) up to recent times (Poonia and Upadhayay 2015). In a layer dated to the 12th century, a pot filled with Quercus sp. (acorns) was found. The use of acorns as food for people or animals has a long tradition as well (Kluk 1808; Ayerdi et al. 2016). In two layers dated to the 11th and 12th centuries, large numbers of Trapa natans nuts occurred. Considering the situation of early medieval Gdańsk, it must have had excellent conditions to grow there in pools and oxbows. The inhabitants of the settlement certainly made use of this very nutritious plant to feed both themselves and their livestock (cf. Karg 2006).

The staple foods of medieval Gdańsk certainly included pulses and charred Vicia faba, V. faba var. minor, Lens culinaris and Pisum sativum were found in the settlement layers dated to the 11th-12th centuries at site 2. Cicer arietinum appears in the 14th century inventory books of the Teutonic castle (Możejko 2006; Badura et al. 2015). Pulses could have been grown in local gardens as suggested by $V$. faba pollen in the layers from the 12th-13th centuries in the town (Święta-Musznicka et al. 2013). Their popularity might have been increased by the arrival of monks at the time, whose monastic rules included eating food based on pulses (Dembińska 1987; Wyrwa 2004).
Vegetables are, in general, highly underrepresented in archaeobotanical materials because they are mostly eaten as bulbs, leaves or shoots which have low potential for being fossilized (Greig 1996). It is also true for Gdańsk, where finds of this group of plants are rather scarce. Our data indicate that Cucumis sativus (cucumber) was eaten in the 11th and 12th century by the people living at site 2 and Allium cepa (onion) was used by Teutonic monks in the 14th century (Możejko 2006). It is not clear if the few remains of other plants of this group represent plants used as vegetables or wild plants which would have been common in meadows and on fallow land, such as Daucus carota (carrot) (ESM Table 2; cf. Mueller-Bieniek 2010).

Plants used as herbs and spices were probably gathered in the wild as well as being grown in local gardens, but exotic imports were limited in this study period. According to our data, Origanum vulgare and Coriandrum sativum were certainly used in the 11th century, then Brassica nigra and Carum carvi appeared in the cultural layers from the 11 th/12th century transition and the 12 th century. The number and frequency of such remains increased in the later archaeobotanical material, in which Betonica officinalis and Juniperus communis appeared in the 12th century, Verbena officinalis in the 12th-13th century, Levisticum officinale in the 13th century and Apium graveolens and Petroselinum crispum in the 14th century. All these were used in various foods for their flavour as well as preserving and healing properties and they were believed to have various therapeutic powers, so for example, $C$. sativum was used to relieve indigestion and against gut parasites (Lonicerus 1679) and B. nigra as a flavouring and medicine (Kluk 1811; Grieve 1971) was regularly listed in the Teutonic Order inventory books (Możejko 2006). The wealthier people had access to more exotic spices, traces of which are, however, generally rare in archaeobotanical samples. The evidence is more often provided by historical sources. The use of Crocus sativus (saffron) and Piper nigrum in the 14th century is confirmed by entries in Teutonic inventory books and by the ledger of the Main Town treasury (Możejko 2006; Badura et al. 2015; Grulkowski 2016). Powdered stigmas of saffron flowers were considered to be a prized addition to food and also an aphrodisiac (Toussaint-Samat 2009). Pepper, on the other hand, was not only valued as a spice, but also used by apothecaries as a basic unit of weight (Wojciechowska 2000) and as a means of payment (Długokęcki 1984).

In the cultural layers of medieval Gdańsk a significant number of remains of fruits and nuts have been preserved. Some of the fruit trees could have been cultivated in local gardens and orchards. Numerous Prunus fruitstones, including $P$. domestica and $P$. domestica ssp. insititia, were found in the 11th and 12th century samples from site 2 , while other sites showed the presence of Malus sp., Pyrus sp., Cerasus vulgaris and $C$. avium. Ribes rubrum appeared in the 14th 
century. Remains of Vitis vinifera and Ficus carica have been found in the features dated to the 12th century and Persica vulgaris to the 12th/13th century transition. It is difficult to decide whether the grape pips are the remains of imported raisins (Gade 2018) or perhaps of locally grown grapes used to make the wine needed by the church. The historical sources tell us that the Cistercians, who settled in Oliwa (now part of Gdańsk) in AD 1178 were obliged to grow vines (Badowicz 2017) and then in the 13th and 14th centuries several vineyards were established in the region, mainly due to the activity of the Teutonic Order (Tandecki 1997). The relatively warm climate in the Baltic region in that period made viticulture possible (Niedźwiedź et al. 2015). Ficus carica reached Gdańsk thanks to the development of long-distance trade and the supply to the local market subsequently grew (Badura et al. 2015). Figs were not only eaten as a delicacy, but were also used to make a medicinal syrup with numerous uses (Compendium 1767; Rosenblum 1855). Fruit and nuts were also collected from the wild. Remains of Vaccinium myrtillus, Fragaria vesca, Rubus idaeus and $C$. avellana were found in the cultural layers of site 2 dated to the 11th/12th century transition and to the 12th century and in the 11th century living quarters of site 8 . The excavation of site 3 revealed a foundation offering placed at the base of the stronghold rampart which included the skeleton of a dog and a large accumulation of Fragaria vesca and V. myrtillus seeds (Badura 2011). Scattered remains of Rubus saxatilis, $R$. caesius, $R$. fruticosus, Oxycoccus palustris, Prunus spinosa, Sambucus nigra, Sorbus aucuparia and Viburnum opulus occurred in the layers dated from the 11th to 14th centuries at several sites (ESM Table 2).

Gdańsk has a long tradition of brewing and drinking beer (Bogucka 1962). Historical documents from the beginning of the fifteenth century mention 378 brewers there (Maciakowska 2011) indicating the already long tradition of the local craft. Fruits of Humulus lupulus occurred regularly and abundantly in the archaeobotanical material. The oldest finds, from the 10th/11th century transition, may have come from wild hops growing in the woods on the Wisła floodplain, where they must have been common. It is not unlikely, however, that hops were already cultivated at the time, as suggested by A. Alsleben (1995) for early medieval Wolin. Hop cultivation was widespread in later periods and they were an important trade item as demonstrated by documents about Granary Island mentioning the job of a hop sorter in the 14th century (Biskup 1978). Significant amounts of hops, malt and beer were listed in the 14th century inventory books of the Teutonic castle (Możejko 2006). A plant which may have been used to make ale in Gdańsk was Myrica gale. Its numerous leaves and buds were found in the 12th century cultural layers at site 2 and a fruit has been found in a 13th century sample from site 9 . In the medieval period, sweet gale was an important ale plant in parts of western and northern Europe (Behre 1999), but we may suspect that in Gdańsk its use was rather limited to brewing traditional ales for Germans and Scandinavians who settled there. Gdańsk lies at the southern limit of the geographical range of $M$. gale (Hegi 1957) and even if it was certainly more frequent in the region in medieval times than today (Herbichowa 1979), it was probably still not common enough to be used as a major brewing ingredient (Latałowa et al. 2007).

Six oilseed taxa are among the useful plants listed for medieval Gdańsk (ESM Table 2). Seeds of Linum usitatissimum and Cannabis sativa were certainly used as food and for various medicinal purposes (Kluk 1805, 1808), but both were grown mainly for their fibre. Numerous remains of shives (stem fragments) and fibres found along with textile tools in the 12th-13th century cultural layers at site 2 indicate local development of textile and rope production (Kamińska and Nahlik 1958; Lechnicki et al. 1961). Large amounts of seeds of Iris pseudacorus from the 12th century, a plant used to make dyes, may be a sign of textile production as well. There is also 14th century historical evidence for the development of such crafts and locations of the workshops in Gdańsk (Maciakowska 2011). Seeds of Papaver somniferum dated to the 11th-14th centuries were a source of oil, but were also used for a "poppy soup" and as a spice and a medicine (Zemanek et al. 2009). Oil could also be obtained from Camelina sativa (12th/13th century transition) and Brassica napus (13th/14th century transition). A few 12th century samples from site 2 contained Cornus sanguinea seeds which are known as a source of oil used for lighting and medical purposes (Kluk 1805).

\section{Conclusions}

The archaeobotanical data from medieval archaeological contexts and sediments in Gdańsk provide unique information on environmental aspects of the town as it developed, the shrinking of natural vegetation and spread of anthropogenic plant communities, changes of hydrological conditions, soil and water pollution and other issues important for the people living in the growing city.

We suggest that the climate change around the 9th-10th centuries was an important factor which enabled local settlement to develop, when alder wetland woods and oxbows began to shrink because of long droughts. Our data are a perfect complement to the existing archaeological and historical information on the beginnings of Gdańsk. They confirm that it was only in the 11th and 12th centuries when significant settlement development started there and that the spatial development of the town was particularly fast in the 14th century.

A comparison of the data from the sites in different parts of Gdańsk indicates that the initially dispersed settlement 
provided habitats for a rich mosaic of vegetation with mostly natural and semi-natural plant communities typical of wet habitats which continued to exist in the town throughout the whole study period. The increasing human activity resulted in the spread of ruderal vegetation rich in plants of moist, nutrient-rich habitats. The pressure from economic and demographic growth resulted in the rising eutrophication of aquatic and land habitats and since the beginning of the 13th century, heavy metal pollution too.

The inhabitants of the growing town created a considerable demand for plants for food and other purposes. The archaeobotanical results suggest an important change in the use of cereals around the 13th century, when the amount of rye increased, which may reflect more consumption of food such as bread. The choice of vegetables and flavourings as well as fruits eaten in Gdańsk distinctly grew in the 12th and 14th centuries following local establishment of religious orders which brought new agricultural practices. Development of regional and long-distance trade was also a factor, which enabled import of exotic goods.

The environmental issues are far less studied by archaeobotanists than those concerning plant use. Gdańsk, with its large network of archaeological sites which have been systematically studied by both pollen and macrofossil analyses supplemented by geochemical data, is certainly one of the leading urban centres in the Baltic region in terms of the knowledge of its past environment. The present review focuses on the oldest history of the city until the end of the 14th century, when demographic and economic development led to increasingly rapid changes in the many aspects of urban structure and function (Maciakowska 2011). The ARCHBOT-UGDA DATABASE contains data from 32 archaeological sites spread over the historical part of Gdańsk, extending into modern times. While discussion of plant use also including the post-medieval period has mostly been summarized (Latałowa et al. 2007; Badura 2011), there is still material in the database providing potential for further research on various aspects of the environmental history of the city.

Acknowledgements The paper was written as a part of the statutory research at the Department of Plant Ecology University of Gdańsk (Grant 530-L145-D581-19). The data are based on the results of the multi-year projects supported by Ministerstwo Nauki i Szkolnictwa Wyższego (Ministry of Science and Higher Education) (Grants N303 097 31/3180, N304 074 32/2799 and N305 081 31/3181) and Narodowe Centrum Nauki (National Science Centre) (Grants 2011/01/B/ ST10/04020 and 2012/05/B/ST10/00243) in Poland. The research would have been not possible without fruitful collaboration with a number of our MSc students and with the archaeologists enabling sampling of the sites and providing us with the information needed for the interpretations; we are particularly grateful to Henryk Paner, Aleksandra Pudło, Zbigniew Polak, Wojciech Dąbrowski, Andrzej Gołembnik, Bogdan Kościński, Zbigniew Misiuk, Robert Krzywdziński, Aleksander Kwapiński and Agnieszka Ruta. We would also like to thank Joanna Jarosińska and Katarzyna Pińska for collaboration and
Marcelina Zimny for her help with on-site and laboratory works. We are thankful to Karl-Ernst Behre, James Greig, Julian Wiethold and an unknown reviewer for their comments on the manuscript.

Open Access This article is licensed under a Creative Commons Attribution 4.0 International License, which permits use, sharing, adaptation, distribution and reproduction in any medium or format, as long as you give appropriate credit to the original author(s) and the source, provide a link to the Creative Commons licence, and indicate if changes were made. The images or other third party material in this article are included in the article's Creative Commons licence, unless indicated otherwise in a credit line to the material. If material is not included in the article's Creative Commons licence and your intended use is not permitted by statutory regulation or exceeds the permitted use, you will need to obtain permission directly from the copyright holder. To view a copy of this licence, visit http://creativecommons.org/licenses/by/4.0/.

\section{References}

Alexandrovskaya EI, Alexandrovskiy AL (2000) History of the cultural layer in Moscow and accumulation of anthropogenic substances in it. CATENA 41:249-259

Alsleben A (1995) Nutzpflanzen aus dem mittelalterlichen Wolin. Zwei ausgewählte Gruppen: Getreide und Lein. Offa 52:185-217

Ayerdi M, Echazarreta-Gallego A, de Francisco-Rodríguez S, Hernández HH, Sarasketa-Garzia I (2016) Acorn cake during the Holocene: experimental reconstruction of its preparation in the western Pyrenees, Iberia. Veget Hist Archaeobot 25:443-457. https ://doi.org/10.1007/s00334-016-0563-1

Badowicz M (2017) Konsumpcja wina w Europie ŚrodkowoWschodniej w XIV-XV wieku - studium zagadnienia. Studia nad dawną Polską 2017:185-195

Badura M (2003) Pimenta officinalis Lindl. (pimento, myrtle pepper) from early modern latrines in Gdańsk (northern Poland). Veget Hist Archaeobot 12:249-252. https://doi.org/10.1007/s0033 4-003-0023-6

Badura M (2010) Szczątki roślin użytkowych w obiektach archeologicznych przy ulicy Rajskiej w Gdańsku. Archeologia Gdańska $4: 253-274$

Badura M (2011) Rośliny użytkowe w dawnym Gdańsku. Studium archeobotaniczne, Wydawnictwo Uniwersytetu Gdańskiego, Gdańsk

Badura M, Latałowa M (2016) Szczątki makroskopowe roślin Z obiektów archeologicznych Zespołu Przedbramia w Gdańsku. In: Pudło A (ed) Zespół Przedbramia ul. Długiej w Gdańsku: Studium archeologiczne. Muzeum Historyczne Miasta Gdańska, Gdańsk, pp 231-247

Badura M, Latałowa M (2018) Warunki osadnictwa i użytkowanie roślin w rejonie jatek rzeźniczych (XIV-XVII w.) - przesłanki archeobotaniczne. In: Pudło A, Ossowski W, Trawicka E (eds) Jatki mięsne w Gdańsku od XIV do XX w. Gdańsk, Muzeum Gdańska, Muzeum Archeologiczne w Gdańsku, pp 565-588

Badura M, Możejko B (2019) The plant element in the diet of the inhabitants of Danzig (Gdańsk), Elbing (Elblagg), and Marienburg (Malbork) during the rule of the Teutonic Order: historical and archaeobotanical perspectives. In: Ecologies of crusading, colonization and religious conversion in the medieval Baltic. (Terra Sacra 1, (ed) Pluskowski A. Brepols, Turnhout, pp 95-110

Badura M, Pińska K (2010) Archeobotaniczne przesłanki na temat obecności roślin leczniczych w dawnym Gdańsku. Panacea $1(30): 32-34$ 
Badura M, Latałowa M, Jarosińska J, Święta J (2004) Rośliny użytkowe w średniowiecznych i nowożytnych materiałach archeobotanicznych z miast północnej Polski (Kołobrzeg, Gdańsk, Elbląg). In: Czaja R, Nawrolska G, Rębkowski M, Tandecki J (eds) Archeologia et Historia Urbana. Muzeum w Elblągu, Elbląg, pp 277-286

Badura M, Jarosińska J, Święta-Musznicka J, Latałowa M (2005) Roślinne składniki diety mieszkańców Kępy Dominikańskiej w Gdańsku na przestrzeni XV-XIX w. - przesłanki archeobotaniczne. In: Morysiński T (ed) Monument. (Studia i Materiały Krajowego Ośrodka Badań i Dokumentacji Zabytków 2) Oficyna Drukarska, Warszawa, pp 479-501

Badura M, Możejko B, Święta-Musznicka J, Latałowa M (2015) The comparison of archaeobotanical data and the oldest documentary records (14th-15th century) of useful plants in medieval Gdańsk, northern Poland. Veget Hist Archaeobot 24:441-454. https://doi. org/10.1007/s00334-014-0501-z

Badura M, Noryśkiewicz AM, Chudziak W, Kaźmierczak R (2018) Environmental context and the role of plants at the early medieval artificial island in the lake Paklicko Wielkie, Nowy Dworek, western Poland. Veget Hist Archaeobot 27:99-110. https://doi. org/10.1007/s00334-017-0617-z

Banerjea RY, Badura M, Kalējs U et al (2017) A multi-proxy, diachronic and spatial perspective on the urban activities within an indigenous community in medieval Riga, Latvia. Quat Int 460:3-21

Behre K-E (1981) The interpretation of anthropogenic indicators in pollen diagrams. Pollen Spores 23:225-245

Behre K-E (1983) Ernährung und Umwelt der wikingerzeitlichen Siedlung Haithabu. Die Ergebnisse der Untersuchungen der Pflanzenreste. (Die Ausgrabungen in Haithabu 8) Wachholtz, Neumünster

Behre K-E (1999) The history of beer additives in Europe - a review. Veget Hist Archaeobot 8:35-48

Behre K-E (2008) Collected seeds and fruits from herbs as prehistoric food. Veget Hist Archaeobot 17:65-73. https://doi.org/10.1007/ s00334-007-0106-X

Beneš J, Kaštowský J, Kočárowá R et al (2002) Archaeobotany of the Old Prague Town defence system, Czech Republic: archaeology, macro-remains, pollen, and diatoms. Veget Hist Archaeobot 11:107-120

Biskup M (1978) Rozwój produkcji rzemieślniczej. In: Cieślak E (ed) Historia Gdańska 1 do roku 1454. Wydawnictwo Morskie, Gdańsk, pp 417-427

Bogucka M (1962) Gdańsk jako ośrodek produkcyjny w XIV-XVII wieku Instytut Historii PAN. PWN, Warszawa

Borderie Q, Ball T, Banerjea R et al (2020) Early middle ages houses of gien (France) from the inside: geoarchaeology and archaeobotany of 9th-11th c. floors. Environ Archaeol 25:151-169. https://doi. org/10.1080/14614103.2018.1534716

Bosi G, Bandini Mazzanti M, Florenzano A et al (2011) Seeds/fruits, pollen and parasite remains as evidence of site function: Piazza Garibaldi - Parma (N Italy) in Roman and Mediaeval times. J Archaeol Sci 38:1,621-1,633

Bosi G, Mercuri AM, Bandini Mazzanti M et al (2015) The evolution of Roman urban environments through the archaeobotanical remains in Modena - Northern Italy. J Archaeol Sci 53:19-31

Brinkkemper O, van Haaster H (2012) Eggs of intestinal parasites whipworm (Trichuris) and mawworm (Ascaris): Non-pollen palynomorphs in archaeological samples. Rev Palaeobot Palynol 186:16-21

Bronk Ramsey C (2017) Methods for summarizing radiocarbon datasets. Radiocarbon 59:1,809-1,833

Brun C (2009) Biodiversity changes in highly anthropogenic environments (cultivated and ruderal) since the Neolithic in eastern France. Holocene 19:861-871
Büntgen U, Myglan VS, Ljundquist FC et al (2011) 2500 years of European climate variability and human susceptibility. Science 331:578-582

Compendium (1767) Compendium Medicum Acutum. Drukarnia Jasnej Góry Częstochowskiej, Częstochowa

Cook S, Clarke A, Fulford M (2005) Soil geochemistry and detection of early Roman precious metal and copper alloy working at the Roman town of Calleva Atrebatum (Silchester, Hampshire, UK. J Archaeol Sci 32:805-812

Cook S, Clarke A, Fulford M, Voss J (2014) Characterising the use of urban space: a geochemical case study from Calleva Atrebatum (Silchester, Hampshire, UK) Insula IX during the late first/early second century AD. J Archaeol Sci 50:108-116

Davis O, Shafer D (2006) Sporormiella fungal spores, a palynological means of detecting herbivore density. Palaeogeogr Palaeoclimatol Palaeoecol 237:40-50

Dembińska M (1987) Wyżywienie mnichów według reguły benedyktyńskiej we wczesnym średniowieczu (VI-XI w.). Studia i Materiały do Dziejów Wielkopolski i Pomorza 16:57-78

Długokęcki W (1984) Świadczenia w pieprzu i szafranie w państwie krzyżackim w XIV-XV w. Zeszyty Naukowe Wydziału Humanistycznego Uniwersytetu Gdańskiego, Historia 14:19-36

Ewert UC (2007) Water, public hygiene and fire control in medieval towns: facing collective goods problems while ensuring the quality of life. Hist Soc Res 32:222-251

Florenzano A, Mercuri AM, Pederzoli A et al (2012) The significance of intestinal parasite remains in pollen samples from medieval pits in the Piazza Garibaldi of Parma, Emilia Romagna, Northern Italy. Geoarchaeology 27:34-47

Florenzano A, Mercuri AM, Carter J (2013) Economy and environment of the Greek colonial system in southern Italy: pollen and NPPs evidence of grazing from the rural site of Fattoria Fabrizio (6th-4th cent. BC; Metaponto, Basilicata). Annali di Botanica 3:173-181

Gade AD (2018) Geoeconomics of raisins production in India. Laxmi Book Publication, Solapur

Gołembnik A (2009) Wyniki prac wykopaliskowych w kościele św. Mikołaja i ich wartość dla rozpoznania topografii najstarszych poziomów osadniczych Gdańska. In: Paner H, Fudziński M, Borcowski Z (eds) Stan badan archeologicznych miast w Polsce. Gdańsk, Muzeum Archeologiczne w Gdańsku, pp 295-308

Green FJ (1984) The archaeological and documentary evidence for plants from the medieval period in England. In: van Zeist W, Casparie WA (eds) Plants and ancient man: studies in palaeoethnobotany. Balkema, Rotterdam, pp 99-114

Greig J (1992) The deforestation of London. Rev Palaeoebot Palynol 73:71-86

Greig J (1996) Archaeobotanical and historical records compared - a new look at the taphonomy of edible and other useful plants from the 11th to the 18th centuries AD. Circaea 12:211-247

Grieve M (1971) A modern herbal. Dover Publications Inc., New York

Grulkowski M (2016) Najstarsze księgi kamlarskie Głównego Miasta Gdańska. Studia i Materiały do Dziejów Kancelarii w Gdańsku 2, serie B, IH PAN, Warszawa

Hall A, Kenward H (2004) Setting people in their environment: plant and animal remains from Anglo Scandinavian York. Aspects of AngloScandinavian York 1959:372-426

Hegi G (1957) Illustrierte Flora von Mitteleuropa, vol. 3/1, Hanser, München

Helama S, Meriläinen J, Tuomenvirta H (2009) Multicentennial megadrought in northern Europe coincided with a global El NiñoSouthern Oscillation drought pattern during the Medieval Climate Anomaly. Geology 37:175-178

Helbæk H (1958) Grauballemandens sidste maaltid (Grauballe Man's last meal). Kuml 1958:83-116 
Helbæk H (1960) Comment on Chenopodium album as a food plant in prehistory. Berichte des Geobotanischen Institutes der Eidg. Techn. Hochschule, Stiftung Rübel 31:16-19

Herbichowa M (1979) Roślinność atlantyckich torfowisk Pobrzeża Kaszubskiego. GTN, Wydz. II Nauk Biologicznych i Medycznych, Acta Biologica 5:1-50

Holliday VT, Gartner WG (2007) Methods of soil P analysis in archaeology. J Archaeol Sci 34:301-333

Hondelink MMA, Schepers M (2020) The common and the rare: a review of Early Modern Dutch plant food consumption based on archaeobotanical urban cesspit data. Veget Hist Archaeobot 29:553-565. https://doi.org/10.1007/s00334-019-00766-x

Hudson-Edwards KA, Maclin MG (1999) Mediaeval lead pollution in the river Ouse at York, England. J Archaeol Sci 26:809-819

Jarosińska J (1994) Stan badań archeobotanicznych średniowiecza na obszarze polskiej części Pobrzeża Bałtyku. (Polish Botanical Studies, Guidebook Series 11) PAN, Kraków, pp. 93-108

Jażdżewski K (1955a) Gdańsk wczesnośredniowieczny w świetle badań z lat 1953 i 1954. Sprawozdania Archeologiczne 1:137-156

Jażdżewski K (1955b) Charakterystyka wczesnośredniowiecznych warstw kulturowych w wykopie głównym na stanowisku $1 \mathrm{w}$ Gdańsku. Studia Wczesnośredniowieczne 3:164-211

Kaczyńska K, Kwapiński A, Sulikowski G (2005) Zmiany parcelacyjne na stanowisku Wyspy Spichrzów w Gdańsku, badania 20002002. In: Paner H, Fudziński M (eds) XVI Sesja Pomorzoznawcza, od wczesnego średniowiecza do czasów nowożytnych 2. Muzeum Archeologiczne w Gdańsku, Gdańsk, pp 373-386

Kamińska J, Nahlik A (1958) Włókiennictwo gdańskie w X-XII wieku. Acta Archaeol Universitas Lodzinsis 6:1-261

Karg S (2006) The water chestnut (Trapa natans L.) as a food resource during the 4th to 1st millennia BC at Lake Federsee, Bad Buchau (southern Germany). Environ Archaeol 1:125-130

Karg S (2007) Long term dietary traditions: archaeobotanical records from Denmark dated to the Middle Ages and early modern times. In: Medieval food traditions in Northern Europe. (Studies in Archaeology \& History 12, (ed) Karg S. Nationalmuseet, Copenhagen, pp 137-160

Karg S, Alsleben A, Hjelle LK, Latałowa M, Lempiäinen T, Sillasoo Ú, Viklund K (2007) Synthesis and a mission for the future. In: Medieval food traditions in Northern Europe. (Studies in Archaeology \& History 12, (ed) Karg S. Nationalmuseet, Copenhagen, pp 181-190

Kisielienė D, Masiulienė I, Daugnora L, Stančikaitė M, Maûeika J, Vaikutienė G, Petrošius R (2012) History of the environment and population of the Old Town of Klaipeda, western Lithuania: multidisciplinary approach to the last millennium. Radiocarbon 54:1,003-1,015

Klichowska M (1959) O wczesnośredniowiecznym chmielu z wykopalisk. Nasiona winorośli z wykopalisk polskich. Z Otchłani Wieków 4:308-310

Kluk K (1805) Dykcyonarz roślinny, vol I. Drukarnia Księży Pijarów, Warszawa

Kluk K (1808) Dykcyonarz roślinny, vol II. Drukarnia Księży Pijarów, Warszawa

Kluk K (1811) Dykcyonarz roślinny, vol III. Drukarnia Księży Pijarów, Warszawa

Kochanowski M (1998) Z problematyki odkryć archeologicznych w obrębie Wielkiego Młyna w Gdańsku. In: Paner H (ed) Gdańsk średniowieczny w świetle najnowszych badań archeologicznych i historycznych. Muzeum Archeologiczne w Gdańsku, Instytut Historii, Uniwersytet Gdański, pp 84-93

Kościński B, Paner H (2005) Nowe wyniki datowania grodu gdańskiego - stanowisko 1 (wyk. I-V). In: Fudziński M, Paner H (eds) XIV Sesja Pomorzoznawcza, vol 2: Od wczesnego średniowiecza do czasów nowożytnych. Gdańsk, Muzeum Archeologiczne w Gdańsku, pp 11-47
Kowalska J, Mazurek R, Gąsiorek M, Setlak M, Zaleski T, Waroszewski J (2016) Soil pollution indices conditioned by medieval metallurgical activity - A case study from Kraków (Poland). Environ Pollut 218:1,023-1,036

Kozáková R, Pokorný P, Havrda J, Jankovská V (2009) The potential of pollen analyses from urban deposits: multivariate statistical analysis of a data set from the medieval city of Prague, Czech Republic. Veget Hist Archaeobot 18:477-488

Kozáková R, Pokorný P, Mařík J, Čulíková V, Boháčová I, Pokorná A (2014) Early to high medieval colonization and alluvial landscape transformation of the Labe valley (Czech Republic): evaluation of archaeological, pollen and macrofossil evidence. Veget Hist Archaeobot 23:701-718. https://doi.org/10.1007/s0033 4-009-0217-7

Krzywdziński R (2009) Stan badań nad budownictwem drewnianym Głównego Miasta Gdańska w XIV wieku. In: Paner H, Fudziński M, Borcowski Z (eds) Stan badań archeologicznych miast w Polsce. Muzeum Archeologiczne, Gdańsk, pp 215-243

Latałowa M (1999) Palaeoecological reconstruction of the environmental conditions and economy in early medieval Wolin - against a background of the Holocene history of the landscape. Acta Palaeobot 39:183-271

Latałowa M, Jarosińska J, Kozłowska M (2001) Szczątki roślin. In: Gołembnik A (ed) Badania archeologiczne terenu przyszłego Centrum Dominikańskiego w Gdańsku: Sezon 2000. (Światowit Supplement, Ser. P: Prehistory and Middle Ages 6). Instytut Archeologii, Uniwersytet Warszawski, Warszawa, pp 185-195

Latałowa M, Badura M, Święta J (2003) Szczątki roślin ze stanowiska archeologicznego przy zbiegu ulic Piwnej i Kaletniczej na terenie Głównego Miasta w Gdańsku. Pomorania Antiqua 19:261-284

Latałowa M, Badura M, Jarosińska J, Święta-Musznicka J (2007) Useful plants in medieval and post-medieval archaeobotanical materials from the Hanseatic towns of northern Poland (Kołobrzeg, Gdańsk and Elbląg). In: Medieval food traditions in Northern Europe. (Studies in Archaeology \& History 12, (ed) Karg S. Nationalmuseet, Copenhagen, pp 39-72

Latałowa M, Badura M, Jarosińska J, Święta-Musznicka J, Pińska K (2009a) Archeobotaniczne przesłanki dotyczące pokarmów roślinnych w Gdańsku, Elblągu i Kołobrzegu na tle danych z innych ośrodków hanzeatyckich północnej Europy (XIII -XVIII w.). In: Paner H, Fudziński M, Borcowski Z (eds) Stan badań archeologicznych miast w Polsce. Gdańsk, Muzeum Archeologiczne, pp 167-185

Latałowa M, Święta-Musznicka J, Pędziszewska A (2009b) Źródła paleobotaniczne do rekonstrukcji wczesnych etapów rozwoju Gdańska. In: Kittel P, Forysiak J, Domańska L (ed) Środowiskowe uwarunkowania lokalizacji osadnictwa. (Środowisko-Człowiek-Cywilizacja 2). Bogucki Wydawnictwo Naukowe, Poznań, pp 175-185

Latałowa M, Święta-Musznicka J, Słowiński M et al (2019) Abrupt Alnus population decline at the end of the first millennium CE in Europe - the event ecology, possible causes and implications. Holocene 29:1,335-1,349. https://doi.org/10.1177/0959683619 846978

Lechnicki F (1955) Szczątki roślinne z wykopalisk gdańskich w latach 1950-1952. Studia Wczesnośredniowieczne 3:252-259

Lechnicki F, Klichowska M, Gupieniec R (1961) Szczątki roślinne ze stanowiska 1 w Gdańsku (wykop główny). Gdańsk Wczesnośredniowieczny 4:5-25

Lonicerus A (1679) Kreuterbuch, künstliche Conterfeytunge der Bäume/Stauden/Hecken/Kräuter/Getreyd/Gewürtze. Mit eigentlicher Beschreibung, derselben Nahmen, in sechserley Sprachen. Ulm 1679 (Reprint Kölbl, Grünwald 1962)

Maciakowska Z (2005) Z badań nad gospodarką wodną w Głównym Mieście w Gdańsku do początku XV w. Kwartalnik Historii Kultury Materialnej 3-4:331-341 
Maciakowska Z (2011) Kształtowanie się przestrzeni miejskiej Głównego Miasta w Gdańsku do początku XV wieku. Muzeum Archeologiczne w Gdańsku, Gdańsk

Maciakowska Z (2015) Kilka uwag na temat średniowiecznego Osieka w Gdańsku. Zapiski Historyczne 80:55-76

Macphail RI, Courty M-A, Goldberg P (1990) Soil micromorphology in archaeology. Endeavour 14:163-171

Mariotti Lippi M, Bellini C, Mori Secci M, Pallecchi P (2013) Archaeobotany in Florence (Italy): landscape and urban development from the late Roman to the Middle Ages. Plant Biosyst 149:1-12

Märkle T (2005) Nutrition, aspects of land use and environment in medieval times in southern Germany: plant macro-remain analysis from latrines (late 11th-13th century AD) at the town of Überlingen, Lake Constance. Veget Hist Archaeobot 14:427-441. https://doi.org/10.1007/s00334-005-0087-6

Matthews W (2010) Geoarchaeology and taphonomy of plant remains and microarchaeological residues in early urban environmants in the Ancient Near East. Quat Int 214:98-113

Mazurek R, Kowalska J, Gasiorek M, Setlak M (2016) Micromorphological and physico-chemical analyses of cultural layers in the urban soil of a medieval city: a case study from Kraków, Poland. CATENA 141:73-84

Mądalski J (1952) Szczątki roślinne z wykopalisk w Gdańsku. Studia Wczesnośredniowieczne 1:97-98

Mercuri AM, Florenzano A, Massamba N'siala I, Olmi L, Roubis D, Sogliano F, (2010) Pollen from archaeological layers and cultural landscape reconstruction: case studies from the Bradano Valley (Basilicata, southern Italy). Plant Biosyst 144:888-901

Mercuri AM, Allevato E, Arobba D et al (2015) Pollen and macroremains from Holocene archaeological sites: A dataset for the understanding of the bio-cultural diversity of the Italian landscape. Rev Palaeobot Palynol 218:250-266

Mirek Z, Piękoś-Mirkowa H, Zając A, Zając M (2002) Flowering Plants and Pteridophytes of Poland. A Checklist, Szafer Institiute of Botany, Polish Academy of Sciences, Kraków

Molaug P (2010) Early urbanisation in Norway. In: Buko A, McCarthy M (eds) Making a medieval town: Patterns of early medieval urbanization. Institute of Archaeology, Polish Academy of Sciences, Warszawa, pp 131-150

Moldenhawer K (1952) Kotewka czyli orzech wodny (Trapa muzzanensis Jäggi) z wykopalisk z średniowiecza w Gdańsku. Acta Soc Bot Pol 21:733-734

Moldenhawer K (1953) Konopie w Polsce w wykopaliskach z wczesnego średniowiecza. Z Otchłani Wieków 22:159-161

Możejko B (2006) Zamek Krzyżacki w Gdańsku w świetle inwentarzy z lat 1384-1446. Studia z Dziejów Średniowiecza 12:115-200

Mueller-Bieniek A (2010) Carrot (Daucus carota L.) in Medieval Kraków (S. Poland): a cultivated form? J Archaeol Sci 37:1725-1730

Mueller-Bieniek A, Bogucki P, Pyzel J, Kapcia M, Moskal-del Hoyo M, Nalepka D (2019) The role of Chenopodium in the subsistence economy of pioneer agriculturalists on the northern frontier of the Linear Pottery culture in Kuyavia, central Poland. J Archaeol Sci 111(105):027

Niecikowski B (2016) Mapa hipsometryczna Trójmiasta. labgis.pl. Accessed 24 July 2019

Niedźwiedź T, Glaser R, Hansson D et al (2015) The historical frame (Past 1000 Years). In, The BACC II author team (eds) Second assessment of climate change for the Baltic Sea basin. Springer, Basel, pp 51-65

Oonk S, Slomp C, Huisman H (2009) Geochemistry as an aid in archaeological prospection and site interpretation: current issues and research directions. Archaeol Prospect 16:35-51

Paner H (1999a) Z badań archeologicznych Gdańska. In: ChoińskaBohdan E, Kwapiński M, Paner H, Szymańska A (eds) Z otchłani wieków Pomorza Gdańskiego. Muzeum Archeologiczne w Gdańsku, Gdańsk, pp 95-119

Paner H (1999b) Archaeological evidence for trade in Gdańsk from the 12th to 17th century. In: Handel D, (Lübecker Kolloquium zur Stadtarchäologie im Hanseraum 2, (eds) Gläser M. SchmidtRömhild, Lübeck, pp 387-402

Paner H (2001) 10th- to 17th-century domestic architecture in Gdańsk. In: Hausbau D, (Lübecker Kolloquium zur Stadtarchäologie im Hanseraum 3, (eds) Gläser M. Schmidt-Römhild, Lübeck, pp 491-509

Paner H (2004) The infrastructure of Gdańsk from the 12th to 17th century. In: Infrastruktur D, (Lübecker Kolloquium zur Stadtarchäologie im Hanseraum 4, (eds) Gläser M. Schmidt-Römhild, Lübeck, pp 323-342

Paner H (2015) Rozwój przestrzenny wczesnośredniowiecznego Gdańska w świetle źródeł archeologicznych. Archaeologica Historica Polona 23:139-161

Petersén AH, Sandvik PU, Sveistrup T (2015) The rural-urban connection as revealed in the terrestrial sediments at Nidarneset, Trondheim, Norway. J Archaeol Sci Rep 2:389-404

Pędziszewska A, Latałowa M (2016) Stand-scale reconstruction of late Holocene forest succession on the Gdańsk Upland (N. Poland) based on integrated palynological and macrofossil data from paired sites. Veget Hist Archaeobot 25:239-254. https://doi.org/10.1007/ s00334-015-0546-7

Pichler SL, Pümpin C, Brönnimann D, Rentzel P (2014) Life in the proto-urban style: the identification of parasite eggs in micromorphological thin sections from the Basel-Gasfabrik Late Iron Age settlement, Switzerland. J Archaeol Sci 43:55-65

Pińska K, Wiloch-Kozłowska R, Badura M (2013) Stanowisko archeologiczne w rejonie ulic: Bogusławskiego, Podwale Przedmiejskie i Zbytki (Teatr Szekspirowski) w Gdańsku w świetle badań archeobotanicznych. In: Fudzińska E (ed) XVIII Sesja Pomorzoznawcza 2, Od późnego średniowiecza do czasów nowożytnych. Muzeum Zamkowe w Malborku, Malbork, pp 149-167

Pokorná A (2017) Tracing the history of synanthropic flora and vegetation in the Czech Republic. Doctoral thesis, Department of Botany, Charles University in Prague, Prague

Pokorná A, Houfková P, Novák J et al (2014) The oldest Czech fishpond discovered? An interdisciplinary approach to reconstruction of local vegetation in medieval Prague suburbs. Hydrobiologia 730:191-213

Polak Z (2009) Uwagi archeologa do historii średniowiecznej kamienicy gdańskiej. In: Paner H, Fudziński M, Borcowski Z (eds) Stan badań archeologicznych miast w Polsce. Muzeum Archeologiczne w Gdańsku, Gdańsk, pp 245-255

Poonia A, Upadhayay A (2015) Chenopodium album Linn: review of nutritive value and biological properties. J Food Sci Tech $52: 3,977-3,985$

Reimer P, Bard E, Bayliss A et al (2013) IntCal13 and Marine13 radiocarbon age calibration curves $0-50,000$ years cal BP. Radiocarbon $55: 1,869-1,887$

Rosenblum B (1855) 900 najlepszych środków domowych przeciw rozlicznym chorobom i cierpieniom człowieka z przyłączeniem niektórych ważniejszych przepisów lekarskich (doświadczonych od kaszlu, kataru...) tudzież skład apteczki domowej przez Hufelanda na wzór dzieła niemieckiego zebrane, ułożone i dwoma traktatami o cholerze i cudownych skutkach zimnej wody pomnożone. S.H. Merzbach,Warszawa

Stančikaitė M, Kisielienė D, Mažeika J, Blaževičius P (2008) Environmental conditions and human interference during the 6th and 13th15 th centuries AD at Vilnius Lower Castle. East Lithuania. Veget Hist Archaeobot 17(Suppl 1):S239-S250

Stivrins N, Brown A, Reitalu T, Veski S, Heinsalu A, Banerjea RY, Elmi K (2015) Landscape change in central Latvia since the Iron Age: multiproxy analysis of the vegetation impact of conflict, 
colonization and economic expansion during the last 2,000 years. Veget Hist Archaeobot 24:377-391. https://doi.org/10.1007/s0033 4-014-0502-y

Stivrins N, Buchan M, Disbrey HR et al (2017) Widespread, episodic decline of alder (Alnus) during the medieval period in the boreal forest of Europe. J Quat Sci 32:903-907

Śliwiński B (2009) Początki Gdańska. Dzieje ziem nad zachodnim brzegiem Zatoki Gdańskiej w I połowie X wieku. Muzeum Historyczne Miasta Gdańska, Gdańsk

Śliwiński B, Możejko B (2017) The political history of Gdańsk from the town beginnings to the sixteenth century. In: Możejko B (ed) New studies in medieval and renaissance Poland and Prussia. The impact of Gdańsk, Routlege, London, pp 17-46

Święta-Musznicka J, Latałowa M (2016) From wetland to commercial centre: the natural history of Wyspa Spichrzów ("Granary Island") in medieval Gdańsk, northern Poland. Veget Hist Archaeobot 25:583-599. https://doi.org/10.1007/s00334-016-0578-7

Święta-Musznicka J, Latałowa M, Szmeja J, Badura M (2011) Salvinia natans in medieval wetland deposits in Gdańsk, northern Poland: evidence for the early medieval climate warming. J Paleolimnol 45:369-383

Święta-Musznicka J, Latałowa M, Badura M, Gołembnik A (2013) Combined pollen and macrofossil data as a source for reconstructing mosaic patterns of the early medieval urban habitats - a case study from Gdańsk. N Poland J Archaeol Sci 40:637-648

Tandecki J (1997) Uprawa winorośli w państwie krzyżackim w Prusach. Zeszyty Naukowe Wyższej Szkoły Pedagogicznej w Bydgoszczy. Studia Historyczne 5:15-32

Toussaint-Samat M (2009) A history of food. Wiley-Blackwell, Hoboken Van Geel B (2001) Non-pollen palynomorphs. In: Smol JP, Birks HJB, Last WM (eds) Tracking environmental change using lake sediments terrestrial algal and siliceous indicators, vol 3. Kluwer, Dordrecht, pp 99-120

Wasylikowa K (1978) Plant remains from early and late medieval time found on the Wawel Hill in Cracow. Acta Paleobot 19:115-200
Wilson C, Davidson D, Cresser M (2008) Multi-element soil analysis: an assessment of its potential as an aid to archaeological interpretation. J Archaeol Sci 35:412-424

Wojciechowska B (2000) O purgowaniu w ziołach, prochach i korzeniach", czyli o lekach i ich dozowaniu w Polsce w XV i XVI wieku. In: Iwańczyk W, Bracha $\mathrm{K}$ (eds) Człowiek i przyroda w średniowieczu w we wczesnym okresie nowożytnym. Wydawnictwo DiG, Warszawa, pp 195-208

Wouters B, Devos Y, Milek K et al (2017) Medieval markets: A soil micromorphological and archaeobotanical study of the urban stratigraphy of Lier (Belgium). Quat Int 460:48-64

Wyrwa AM (2004) W kuchni i przy stole „szarych mnichów”, czyli o wyżywieniu cystersów w świetle źródeł normatywnych zakonu oraz wybranych źródeł pisanych, archeologicznych i przyrodniczych. Archeol Hist Pol 14:51-113

Zbierski A (1978a) Rozwój przestrzenny Gdańska w IX-XIII wieku. In: Cieślak E (ed) Historia Gdańska, t. 1 do roku 1454. Wydawnictwo Morskie, Gdańsk, pp 71-125

Zbierski A (1978b) Wytwórczość rzemieślnicza. In: Cieślak E (ed) Historia Gdańska, t. 1 do roku 1454. Wydawnictwo Morskie, Gdańsk, pp 126-172

Zbierski A (1978c) Ośrodek handlowo-portowy. In: Cieślak E (ed) Historia Gdańska, t. 1 do roku 1454. Wydawnictwo Morskie, Gdańsk, pp 194-223

Zemanek A, Zemanek B, Klepacki P, Madeja J (2009) The poppy (Papaver) in old Polish botanical literature and culture. In: Morel J-P, Mercuri AM (eds) Plants and culture: seeds of the cultural heritage of Europe. Edipuglia, Bari, pp 217-226

Publisher's Note Springer Nature remains neutral with regard to jurisdictional claims in published maps and institutional affiliations. 